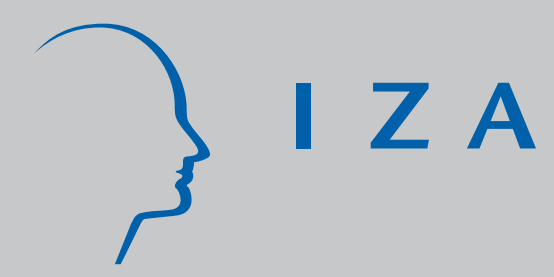

IZA DP No. 802

Assimilation via Prices or Quantities?

Labor Market Institutions and Immigrant Earnings Growth in Australia, Canada, and the United States

Heather Antecol

Peter Kunn

Stephen J. Trejo

J une 2003 


\title{
Assimilation via Prices or Quantities? Labor Market Institutions and Immigrant Earnings Growth in Australia, Canada, and the United States
}

\author{
Heather Antecol \\ Claremont McKenna College \\ Peter Kuhn \\ University of California at Santa Barbara \\ and IZA Bonn \\ Stephen J. Trejo \\ University of Texas at Austin \\ and IZA Bonn
}

Discussion Paper No. 802

June 2003

IZA

P.O. Box 7240

D-53072 Bonn

Germany

Tel.: +49-228-3894-0

Fax: +49-228-3894-210

Email: iza@iza.org

This Discussion Paper is issued within the framework of IZA's research area Mobility and Flexibility of Labor. Any opinions expressed here are those of the author(s) and not those of the institute. Research disseminated by IZA may include views on policy, but the institute itself takes no institutional policy positions.

The Institute for the Study of Labor (IZA) in Bonn is a local and virtual international research center and a place of communication between science, politics and business. IZA is an independent, nonprofit limited liability company (Gesellschaft mit beschränkter Haftung) supported by Deutsche Post World Net. The center is associated with the University of Bonn and offers a stimulating research environment through its research networks, research support, and visitors and doctoral programs. IZA engages in (i) original and internationally competitive research in all fields of labor economics, (ii) development of policy concepts, and (iii) dissemination of research results and concepts to the interested public. The current research program deals with (1) mobility and flexibility of labor, (2) internationalization of labor markets, (3) welfare state and labor market, (4) labor markets in transition countries, (5) the future of labor, (6) evaluation of labor market policies and projects and (7) general labor economics.

IZA Discussion Papers often represent preliminary work and are circulated to encourage discussion. Citation of such a paper should account for its provisional character. A revised version may be available on the IZA website (www.iza.org) or directly from the author. 
IZA Discussion Paper No. 802

June 2003

\section{ABSTRACT \\ Assimilation via Prices or Quantities? Labor Market Institutions and Immigrant Earnings Growth in Australia, Canada, and the United States*}

How do international differences in labor market institutions affect the nature of immigrant earnings assimilation? Using 1980/81 and 1990/91 cross-sections of census data from Australia, Canada, and the United States, we estimate the separate effects of arrival cohort and duration of destination-country residence on immigrant outcomes in each country. Relatively inflexible wages and generous unemployment insurance in Australia suggest that immigrants there might improve themselves primarily through employment gains rather than wage growth, and we find empirically that employment gains explain all of the labor market progress experienced by Australian immigrants. Wages are less rigid in Canada and the United States than in Australia, with the general consensus that the U.S. labor market is the most flexible of the three. We find that wage assimilation is an important source of immigrant earnings growth in both Canada and the United States, but the magnitude of wage assimilation is substantially larger in the United States. These same general patterns remain when we replicate our analyses for two subsamples of immigrants - Europeans and Asians that are more homogeneous in national origins yet still provide sufficiently large sample sizes for each country.

JEL Classification: J38, J64

Keywords: immigrant assimilation, labor market flexibility

Corresponding author:

Stephen J. Trejo

Department of Economics

University of Texas

Austin, TX 78712-1173

USA

Email: trejo@eco.utexas.edu

\footnotetext{
* We thank the University of California's Pacific Rim Research Grant program for support.
} 


\section{Introduction}

International differences in labor market institutions, such as unionization and income support policies, have recently been argued to cause international differences in a variety of economic outcomes. These outcomes include the degree of wage inequality (DiNardo, Fortin, and Lemieux 1996; Blau and Kahn 1996); the manner in which economies respond to adverse shocks to the demand for unskilled labor (Card, Kramarz, and Lemieux 1999; McDonald and Worswick 2000); the size of the gender wage gap (Blau and Kahn 2000); the magnitude of wage losses experienced by displaced workers (Kuhn 2002); youth unemployment (Abowd et al. 2000); work hours (Bell and Freeman 2001); technical progress (Moene and Wallerstein 1997); and the amount of labor reallocation across industries (Bertola and Rogerson 1997).

Perhaps surprisingly, one potentially important consequence of labor market institutions that has not yet been examined is the process via which immigrants are absorbed into a nation's economy (Chiswick 1978; Borjas 1985). The vast majority of existing studies of immigrant assimilation focus on a single country and restrict attention to a single dimension of immigrant assimilation, typically the wages or earnings of employed immigrants. ${ }^{1}$ Since the precise definitions of samples, time periods, variables, and regression specifications can all affect assimilation estimates, a credible examination of the effects of institutions needs to incorporate multiple countries in a single paper. Further, since labor market institutions are as likely to affect

\footnotetext{
${ }^{1}$ A notable exception is Borjas (1988). He considers two cross-sections of data for Canada and the United States (1970/71 and 1980/81) and a single cross-section for Australia. Aside from updating his study, the current paper expands on it in two main ways. First, we are able to distinguish assimilation effects from cohort quality changes in Australia. This turns out to be critical, because Australia is one of our "extreme" cases of institutional structure, and because Borjas' interpretation of the Australian data is based on an assumption (that wage assimilation could not be negative) that turns out to be violated. Second, we distinguish employment and wage assimilation and examine this distinction in the context of labor market institutions. Miller and Neo (2001) compare the United States and Australia
} 
the form that assimilation takes (in particular, the distinction between wage and employment adjustments) as its overall level, it is critical that more than one dimension of the assimilation process be considered. Thus, the goal of this paper is to analyze the form and amount of immigrant assimilation in three countries-Australia, Canada and the United States-using (as far as possible) identical samples for the same period of time, and to consider the role that institutional differences play in explaining any international differences we see. ${ }^{2}$

We argue, first, that the main institutional differences likely to be relevant to the immigrant experience in these three countries involve wage-setting and income support. Next we hypothesize that differences in these two institutional dimensions should have the following effects on the immigrant assimilation process: 1 . Relative to natives, newly-arrived immigrants should have the lowest employment rates in Australia, and the highest in the United States. 2. Largely as a consequence of the previous point, immigrant employment rates should rise most rapidly with time in the host country in Australia and least rapidly in the United States. 3. Relative to natives, newly-arrived immigrants who are employed should have the highest wages in Australia and the lowest in the United States. 4. Relative to natives, immigrant wage rates should rise most rapidly with time in the host country in the United States and least rapidly in Australia. 5. Decomposing the total earnings growth of a cohort of newly-arrived immigrants into the portion due to increased employment rates versus wage growth, we expect the share due to wage growth to be highest in the United States and the lowest in Australia, with Canada

\footnotetext{
using a single cross-section in each country.

${ }^{2}$ Angrist and Kugler (2003) investigate a different aspect of the interaction between immigration and labor market institutions: how the impact of immigrants on natives varies with labor market flexibility. Across European Union countries, they find that immigration tends to depress native employment more when institutions restrict flexibility.
} 
between these two extremes.

In the main, our hypotheses are confirmed: new immigrants face by far the largest wage disadvantage in the United States, but also experience by far the greatest rate of wage growth after arrival. Also, wage growth accounts for the highest share of total earnings assimilation in the United States and the lowest in Australia. Thus, compared to the United States, the investment undertaken by immigrants to Australia and Canada consists disproportionately of "waiting" for a good job to open up rather than accumulating skills while on the job. Somewhat more surprisingly, wage assimilation in Australia is in fact negative, a result driven in part by the fact that some immigrant cohorts earn a positive wage premium upon arrival, and they then assimilate downwards towards the Australian norm. It follows that the lower rate of immigrant wage growth in Australia cannot be just a mechanical result of the smaller distance between the rungs of its "earnings ladder". Instead our results suggest that, as an optimizing response to the smaller gains to be had by climbing the ladder, immigrants to Australia choose not to make the investments required to climb it, i.e. immigrants to low-wage-dispersion countries advance less because there is "nowhere to go". Finally, and also somewhat unexpectedly, we do detect employment assimilation in all three countries, but do not find large differences in the rate of employment assimilation between the countries.

\section{Labor Market Institutions and Immigrant Assimilation}

The similarities between our three countries that make them, collectively, a good "laboratory" in which to compare the immigrant experience are well known; they include a high level of economic development; a common Anglo-Saxon cultural heritage, language and legal 
system; a definition of citizenship that is based on country of birth rather than ethnicity; the feature of being recently colonized by Europeans with only small aboriginal populations remaining in the country; relatively low population densities; a long tradition of immigration; and large immigrant population shares by international standards. From common roots, however, the countries have diverged considerably in the institutions regulating their labor markets. The goal of this paper is to look for effects of these emergent institutional differences on the economic experiences of twentieth-century immigrants to Australia, Canada, and the United States.

We argue that two main institutional differences are likely to have substantial effects on immigrants to these three countries: wage-setting institutions and income support policies. ${ }^{3}$ Concerning the wage-setting process, Table 1 shows the well-known difference in union density between the United States and Canada, as well as the well-known decline in U.S. union density between 1980 and 1990. While union density in both countries is low by OECD standards, by the end of our sample period union density in Canada was more than double that in the United States (36 versus 16 percent). In both countries, coverage is only marginally greater than density, and wage bargaining is extremely decentralized (among 19 OECD countries, only one country ranks lower than Canada and the United States in terms of bargaining centralization).

\footnotetext{
${ }^{3}$ On a third dimension that features prominently in some recent international labor market comparisonsquantity-based restrictions such as maximum hours laws and employment protection laws (EPLs)—differences among our three countries are much less extreme. If anything, Canada has the most stringent EPLs of these three countries (see Kuhn 2002), but the restrictions in all three are very low by international standards. (In contrast, Australia's wagesetting institutions are easily as stringent as many in Europe.) Another institution affecting the immigrant experienceadmissions criteria - does differ substantially among the three countries. However, Borjas (1993) and Antecol, CobbClark and Trejo (2003) show that this works almost exclusively by changing the mix of immigrant source countries, in particular by changing the share of immigrants from Latin America. By controlling for region of origin we can thus net out most of the effects of different admissions criteria.
} 
Australia's wage-setting process differs dramatically from the North American norm. Union membership rates are higher than both Canada and the United States, and declining over our sample period, but the most dramatic difference is in union coverage: in both our sample years, 80 percent or more of Australian workers' wages were determined by collective bargaining agreements. Further, this wage-setting process is highly centralized and co-ordinated on the national level. In 1990, Australia was ranked first (tied with Austria, Belgium, Finland, Norway, Portugal and Sweden) among 19 countries in bargaining centralization by the OECD. ${ }^{4}$

The consequences of these different wage-setting institutions for wage dispersion can be seen in panel B of Table 1. As Blau and Kahn (1996) have argued, high levels of union coverage tend to be associated with low levels of wage dispersion, and this is certainly borne out in our data. By all measures-the $90 / 10$ ratio (ratio of the $90^{\text {th }}$ to the $10^{\text {th }}$ percentiles of the weekly earnings distribution), 90/50 ratio, 50/10 ratio, or the standard deviation of log wagesAustralia had the most compressed wage distribution in both years of our data, and the United States the most dispersed. Canada stands between these two extremes on most measures, though it is tied with the Unites States on two of these measures in 1990, perhaps reflecting a more severe recession at that time. All three countries exhibit increasing wage inequality between 1980 and 1990.

Concerning the income support available to unemployed workers, an aggregate, comparable index of benefit generosity computed by the OECD in Table 1 shows similar overall

\footnotetext{
${ }^{4}$ During our sample period, the dominant institution in Australian wage-setting was the "awards" system, a system whereby unions, employers and government representatives met at the national level to negotiate wage rates specific to hundreds of occupations. Although firms were free to pay above-award wages, this was rare in practice. Thus, for all intents and purposes, Australian wages during our sample period were centrally administered at the occupation level. Statutory minimum wages were set at similar (low) fractions of the average wage in Canada and the
} 
replacement rates in Canada and Australia, and a much lower rate in the United States. While this probably summarizes overall generosity reasonably well, there are a number of reasons to suspect that these figures understate the differences among the three countries, especially as it affects immigrants. One such difference is the take-up rate of unemployment insurance (UI) benefits: in 1990, the ratio of UI beneficiaries to the total number of unemployed was 34 percent in the United States, 82 percent in Australia, and 87 percent in Canada. ${ }^{5}$ Thus it is much less likely that an unemployed worker in the United States will actually receive UI benefits than in Australia or Canada. Second, the Australian income support system has three features that make it especially generous for immigrants: unlike the United States and Canadian systems, eligibility does not require prior employment, recent immigrants are not explicitly disqualified from receiving benefits, and benefits do not depend on previous wages. Furthermore, in Australia these benefits are payable for an indefinite period, in contrast to maximum entitlement periods of a year in Canada and 26 weeks in the United States. On balance, it appears that Australia's income support system is the most generous to immigrants, and both Canada and Australia are clearly more generous than the United States.

Given that during our sample period Australia had a much more compressed wage distribution and more generous income support for unemployed immigrants than the United States, with Canada between these extremes on both these dimensions, how might one expect

United States, and they did not exist in Australia because they were superseded by the awards system.

${ }^{5}$ OECD, 1994, Table 8.4, plus CANSIM Series v384773 [the OECD's table includes UI and welfare cases for Canada; thus we retrieved our own beneficiary counts from Statistics Canada's CANSIM database]. Australian figures refer to 1991. For Canada, our figures include regular UI beneficiaries only (thus they exclude UI benefits for job training, maternity, sickness, etc.). As noted, Australia has only a means-tested program — these figures refer to it. US figures, like Canada's include UI claimants only (thus excluding welfare). In all cases the count of beneficiaries refers to an annual average stock (not to the total number of persons receiving benefit at any time during the year). 
the immigrant assimilation process to differ between these countries? Most obviously, one would expect a minimum-wage effect: to the extent that high, centrally-administered wage floors prohibit employment below a certain wage, unskilled (or poorly-connected) workers may not be able to find employment as easily. As in the Harris-Todaro (1970) model of rural-urban migration, immigrants will have to wait in a queue before finding higher-wage jobs. Thus we expect a higher incidence of unemployment on arrival, and a greater decline in unemployment with time in the country. A second effect, reinforcing the first, is a reservation-wage effect: more generous income support while unemployed should make immigrants more selective about new jobs, choosing to remain unemployed longer. Thus, economic assimilation should consist more of "waiting" in a queue for a good job to arrive, and less of acquiring skills while employed.

A third effect of institutions is a purely mechanical effect of national wage compression on the relative wage growth rates of immigrants. Suppose that, over the course of his first ten years in the country, an immigrant to Australia advances five percentiles in the native wage distribution, and the same is true of an immigrant to the United States. Simply because the rungs of the U.S. wage "ladder" are farther apart, the immigrant to the United States will experience greater wage growth (even relative to natives) than the immigrant to Australia. ${ }^{6}$ Another expected effect of wage compression is not so mechanical: suppose that the investment required to rise one rung on the ladder (e.g. learning English) is equally costly in the United States and Australia. Then—for the same reason that Bell and Freeman (2001) argue that Americans work harder than Germans_-immigrants to Australia will be less inclined to make

\footnotetext{
${ }^{6}$ For the United States, this "mechanical" effect of wage structure on the immigrant-native wage gap has been explored by Butcher and DiNardo (1998) and Lubotsky (2001).
} 
these investments because there is less to be gained in a compressed-wage economy. ${ }^{7}$

In sum, given the institutional differences between these three countries during the time period in question, we expect the following differences in the immigrant assimilation process: relative to natives, immigrant employment rates should be lowest on arrival, but grow most rapidly with time in Australia. In contrast, immigrant wage rates should be highest on arrival, but grow least rapidly with time in Australia. Results for the United States should be the opposite of this, with Canada between the two extremes. Overall, decomposing the total earnings growth of a cohort of newly-arrived immigrants into the portion due to employment versus wage growth, we expect the share due to wage growth to be highest in the United States and lowest in Australia, with Canada between these two extremes.

\section{Data}

We analyze individual-level data from the 1981 and 1991 Australian and Canadian censuses and the 1980 and 1990 U.S. census. For each country, these censuses provide comparable cross-section data at two points in time on demographic characteristics and labor force behavior, as well as the requisite information on country of birth and year of arrival for foreign-born individuals (henceforth referred to as immigrants). Having at least two crosssections of data for each country is advantageous for estimating immigrant assimilation effects, as we explain in the next section, and the large samples of individuals available in census data produce relatively precise estimates. The Australian data constitute one-percent samples of the

\footnotetext{
${ }^{7}$ While we do not incorporate income taxes explicitly into our analysis, income tax differentials across the countries reinforce this effect: the much-higher marginal rates in Canada than the United States, for example, reduce the
} 
population, the Canadian data are three-percent samples, and the U.S. data are five-percent samples. ${ }^{8}$

We restrict our analysis to men between the ages of 25 and 59 who are not institutional residents. We exclude women in order to minimize biases arising from selective labor force participation, and we choose this age range so as to focus on men who have completed their formal schooling and who have a strong attachment to the labor market. By comparing outcomes for immigrants with those for natives who reside in the same destination country, natives can serve as a control for cross-country differences in social or economic conditions or in how the census data were collected. To increase comparability of the native samples across countries and improve their usefulness as a control group, we exclude non-whites from the native (but not the immigrant) samples. ${ }^{9}$ In addition, residents of the Atlantic Provinces and the Territories are excluded from the Canadian samples, because for these individuals the information about country of birth and year of immigration is not reported in sufficient detail.

Finally, in order to avoid complications that arise with immigrants who arrived as children, we exclude all foreign-born individuals whose age and arrival cohort imply any possibility that they entered the destination country prior to age 16 . Immigrants who arrive as children, and who therefore acquire much of their education and all of their work experience in the destination country and who are more likely to speak the destination-country language

incentive to acquire host-country-specific skills even more.

${ }^{8}$ The U.S. samples are much larger than the samples from the other two countries. To lighten the computational burden, we employ 0.1-percent (or one in a 1000) samples of U.S. natives, but we use the full fivepercent samples of U.S. immigrants, and we use the full samples of natives and immigrants available in the Australian and Canadian data.

${ }^{9}$ In particular, we exclude blacks, Asians, Hispanics, and aboriginals from the native samples for each 
fluently, often enjoy greater economic success than immigrants who come as adults (Kossoudji 1989; Friedberg 1991). Given the age and other restrictions typically used to construct analysis samples, the average age at arrival within the extracted subsample of a cohort falls with duration of residence in the destination country, because as an immigrant arrival cohort ages, its youngest members enter the sample and its oldest members leave the sample. These factors combine to produce a spurious correlation between immigrant outcomes and duration of destination-country residence. Because the inclusion of immigrants who arrived as children can bias estimates of assimilation effects, we exclude child immigrants from our samples. ${ }^{10}$

\section{Empirical Framework}

Our goal is to compare the relative importance of employment versus wage adjustments in accounting for the labor market assimilation of immigrants to Australia, Canada, and the United States. We start with the identity $E=p w$, where $E$ denotes the expected earnings of an immigrant, $p$ is the probability that the immigrant is employed, and $w$ is the wage paid to the immigrant when he is employed. It is perhaps most natural to think of $p$ as the fraction employed in a cohort of immigrants, $w$ as the mean earnings of the employed members of the cohort, and $E$ as the mean earnings of all members of the cohort (including those who are not employed and therefore have zero earnings). Consider how the cohort's earnings potential evolves over time as its members adapt to the destination country's labor market. To a first-

destination country.

${ }^{10}$ In their analysis of the unemployment experiences of Australian immigrants, McDonald and Worswick (1999b) find it important to distinguish between immigrants who arrived as children and those who arrived as adults. 
order approximation, the identity implies that

$$
\% \Delta E=\% \Delta p+\% \Delta w
$$

In percentage terms, the growth in expected earnings arising from immigrant assimilation is equal to the sum of assimilation's impacts on employment rates and wages. Equation (1) provides a useful decomposition of the labor market assimilation of immigrants into employment and wage components. To implement equation (1) empirically, we need estimates of how assimilation affects the employment and wage opportunities of immigrants. In this context, assimilation represents the independent effect of duration of destination-country residence on immigrant outcomes. In other words, how do immigrant outcomes change with greater exposure to the host country?

We adopt the regression framework developed by Borjas $(1985,1995)$ for estimating the separate effects of arrival cohort and duration of destination-country residence on immigrant outcomes. This framework exploits the availability of comparable cross-section data from at least two different points in time. Without strong restrictions, it is impossible to distinguish immigrant cohort and assimilation effects using just a single cross-section of data because, at any given point in time, variation across immigrants in years of destination-country residence arises only from differences in immigrants' dates of entry. With repeated cross-sections, however, outcomes for immigrant arrival cohorts can be tracked over time, and the trick then becomes to isolate changes due to assimilation from changes caused by different economic conditions in the survey years being compared (i.e., period effects). The most popular solution to this problem, and the one adopted here, is to estimate period effects from the outcome changes experienced by natives. After netting out these estimates of the period effects, remaining changes for 
immigrant cohorts are attributed to assimilation. ${ }^{11}$

To be explicit, let $y_{j}^{g}$ represent the outcome for individual $j$, where the superscript $g$ takes on the values $I$ for immigrants and $N$ for natives. Pooling data from the 1981 and 1991 censuses, ${ }^{12}$ immigrant outcomes are determined by the equation

$$
y_{j}^{I}=C_{j} \lambda^{I}+A_{j} \delta^{I}+\pi T_{j}+\left(1-T_{j}\right) X_{j} \beta_{81}^{I}+T_{j} X_{j} \beta_{91}^{I}+\varepsilon_{j}^{I},
$$

where the vector $C$ is a set of mutually exclusive dummy variables identifying immigrant arrival cohorts, the vector $A$ is a set of mutually exclusive dummy variables indicating how long an immigrant has lived in the destination country, $T$ is a dummy variable marking observations from the 1991 census, the vector $X$ contains other determinants of outcomes, $\varepsilon$ is a random error term, and the remaining parameters are the objects of estimation. This specification gives each immigrant arrival cohort its own intercept, and differences in these intercepts represent permanent outcome differentials between cohorts. The coefficients of the duration of destination-country residence dummies measure the effects of immigrant assimilation on the outcome variable. In addition, the coefficients of the variables in $X$ are allowed to vary across census years, with the subscripts 81 and 91 indicating the survey year of a particular parameter vector.

The corresponding equation for natives is

$$
y_{j}^{N}=\alpha^{N}+\pi T_{j}+\left(1-T_{j}\right) X_{j} \beta_{81}^{N}+T_{j} X_{j} \beta_{91}^{N}+\varepsilon_{j}^{N},
$$

\footnotetext{
${ }^{11}$ A key assumption of this approach is that compositional changes in the subsample of an immigrant cohort observed—such as those caused by emigration, mortality, and labor force entry and exit—do not bias measured outcome changes.

12 These are the years relevant for the Australian and Canadian census data. For the U.S. census data, the corresponding years are 1980 and 1990.
} 
where $\alpha^{N}$ is the intercept for natives, and the arrival cohort and duration of destination-country residence variables are excluded from this equation because they are not relevant for natives.

To see the identification problem in equation (2), it is easiest to think of $C, A$, and $T$ as being scalar variables denoting, respectively, an immigrant's year of arrival in the destination country, years since arrival, and survey year. In this case, $C+A=T$, which implies that we cannot estimate the separate effects of these variables without imposing some type of restriction. An analysis of immigrant outcomes must confront the classic problem of distinguishing cohort, age, and period effects. The identifying restriction imposed in equations (2) and (3) is that the period effect $\pi$ is the same for immigrants and natives, as indicated by the absence of a superscript on this parameter. In essence, the period effect is estimated from natives, and this information is used to identify cohort and assimilation effects for immigrants. To estimate the parameters of equations (2) and (3), we pool observations on immigrants and natives from both years of census data into a single regression, and then impose the restrictions implicit in these equations by introducing the appropriate interaction terms between nativity, the 1990/91 census dummy, and the other explanatory variables.

\section{Estimation Results}

In this section, we use the empirical approach just described to estimate the impact of assimilation on the employment and wage opportunities of immigrants to Australia, Canada, and the United States. Interpreting these estimates in the context of equation (1), we then compare the relative importance of employment versus wage adjustments in accounting for immigrant labor market assimilation in these three countries. Before discussing the regression results, 
however, we first introduce our two outcome variables and describe how they vary with nativity and immigrant arrival cohort.

Table 2 presents employment rates for our samples of native and immigrant men in the two census years for each of the three countries. Recall that our samples include men ages 2559, with non-whites excluded from the native but not the foreign-born samples, and with the additional exclusion of immigrants who arrived in the destination country as children. Standard errors are shown in parentheses and cell sample sizes are in brackets. The reported rates represent the percentage of men in each cell who were employed during the census survey week. Here, and throughout the paper, the intervals listed for immigrant arrival cohorts are those defined in the Australian and Canadian data; the slightly different immigrant cohorts defined in the U.S. data are as follows: pre-1960, 1960-64, 1965-69, 1970-74, 1975-79, 1980-84, and 1985-90. ${ }^{13}$ The 1991 Australian census does not distinguish 1960s arrivals from earlier immigrants, and therefore "pre-1971" is the most precise arrival cohort that can be defined consistently across censuses for Australian immigrants. For Canada and the United States, however, immigrants arriving during these years are disaggregated into "1966-70," “1961-65," and "pre-1961” cohorts.

Overall, native men tend to have higher employment rates than their foreign-born counterparts, with the only exception occurring in the 1981 data for Canada. In 1990/91, for example, employment rates were 86 percent for natives versus 80 percent for immigrants in Australia, 86 percent for natives versus 83 percent for immigrants in Canada, and 89 percent

\footnotetext{
${ }^{13}$ For ease of exposition, we will refer to particular immigrant cohorts using the year intervals that pertain to the Australian and Canadian data, with the implied understanding that in the U.S. data the actual cohort intervals begin
} 
for natives versus 85 percent for natives in the United States. ${ }^{14}$ In all three countries, male employment rates fell for both natives and immigrants between 1980/81 and 1990/91, although the declines were much smaller in the United States (drops of less than a percentage point) than elsewhere (drops of 4-6 percentage points for natives and 7-9 points for immigrants).

Within a given cross-section, immigrants in all three countries display a marked jump in employment rates between the two most recent arrival cohorts, and then employment propensities are relatively stable across the remaining cohorts. Consider, for example, the 1981 Australian data. The employment rate is below 80 percent for men who immigrated within the last five years (1976-80 arrivals), but it shoots up to 90 percent for immigrants who have spent between five and ten years in Australia (1971-75 arrivals), and it holds steady at 89 percent for immigrants with over ten years of Australian residence (pre-1971 arrivals). A qualitatively similar pattern emerges in each of the other cross-sections, regardless of country or survey year. This pattern could indicate that immigrants experience a substantial amount of employment adjustment during their initial five or ten years in the destination country, but an alternative explanation is that the cross-sectional data reflect permanent employment differences between immigrant cohorts.

The availability of a second cross-section for each country allows us to follow immigrant cohorts through time, and this type of longitudinal analysis reveals that the depressed employment of recent arrivals primarily represents an immigrant adjustment process rather than permanent cohort differences. Consider, for example, the 1976-80 cohort of immigrants to the and end one year earlier.

${ }^{14}$ It should be noted that our exclusion of non-whites from the native but not the immigrant samples raises 
United States. In 1980, shortly after arrival, the employment rate of this cohort (78 percent) was about 10 percentage points below that of natives or earlier immigrant cohorts. Over the next decade, however, the employment rate of 1976-80 arrivals rose by 11 percentage points, whereas employment propensities either remained constant or fell for natives and the other immigrant cohorts. By 1990, the 1976-80 cohort had the same employment rate as natives (89 percent) and the highest rate of any immigrant cohort. The same sort of convergence occurs in Australia and Canada, where the 1976-80 arrival cohorts experienced rising employment rates over the 1980s even as natives and all other immigrant cohorts suffered noticeable declines. These employment gains for the most recent immigrant arrivals relative to natives and earlier immigrants suggest that a discrete jump in immigrant labor force activity occurs during the first decade of adaptation to the destination-country labor market. To accommodate the apparent nonlinearity of immigrant employment adjustment, the regressions reported below will employ a flexible specification of immigrant assimilation effects.

Table 3 presents the same type of information for the natural logarithm of wages, our other outcome variable. In addition to the sample restrictions that pertain to Table 2, we now further limit attention to employed men. For Canada and the United States, we use weekly earnings to represent wages. Unfortunately, the Australian census does not distinguish an individual's earnings from his other sources of income, so for Australia we are forced to use weekly personal income as our proxy for wages. ${ }^{15}$ To facilitate comparisons across years within each country, the figures in Table 3 have been converted to 1990 dollars for Australia the relative employment rates of natives.

${ }^{15}$ For all three countries, our measure of wages includes self-employment earnings as well as wage and salary 
and Canada and to 1989 dollars for the United States. No attempt was made to adjust for the rate of exchange between the various currencies, however, so it is not meaningful to compare across countries the levels of log wages reported in Table 3.

In Australia and Canada, immigrants as a group have average wages that are quite close to those of native workers (immigrant-native wage differentials of less than 5 percent), whereas in the United States immigrants earn substantially less than natives (the wage advantage for U.S. natives is 16 percent in 1980 and 24 percent in 1990). ${ }^{16}$ Real wages fell slightly over the 1980 s for native workers in all three countries and for foreign-born workers in Australia, but Canadian and U.S. immigrants suffered larger declines of about 10 percent. In Australia, average wages vary remarkably little by nativity or across immigrant arrival cohorts. Wage gaps between the highest-paid and lowest-paid cohorts of Australian immigrants are just 5 percent in 1981 and 6 percent in 1991, and in each year the average wages of Australian natives fall within the relatively narrow range of mean wages observed across immigrant cohorts. In contrast, wages vary enormously across immigrant cohorts in Canada and the United States, with more recent arrivals typically earning much less than earlier immigrants and natives. In 1990/91, for example, the newest Canadian and U.S. immigrants (1986-91 arrivals) earned roughly 30 percent less than immigrants who came ten years earlier (1976-80 arrivals) and at least 50 percent less than immigrants who came twenty years earlier (1966-70 arrivals).

These cross-sectional comparisons suggest that immigrant wage assimilation is minimal

earnings.

\footnotetext{
${ }^{16}$ For expositional convenience, throughout the paper we will treat log wage differences as representing percentage wage differentials, although we recognize that this approximation becomes increasingly inaccurate for log differences on the order of .25 or more in absolute value. In such instances, one can calculate the implied percentage
} 
in Australia and substantial in Canada and the United States, but, as discussed above, only a longitudinal analysis can hope to distinguish true assimilation from permanent differences between arrival cohorts. The longitudinal evidence in Table 3 confirms the qualitative patterns of assimilation suggested by cross-sectional wage differences between immigrant cohorts. In Australia, wage growth between 1981 and 1991 is close to zero for each of the arrival cohorts and for natives, so there is no indication that these additional ten years of Australian residence produced wage gains for immigrants relative to natives. In Canada and the United States, however, all post-1960 arrival cohorts experienced rising real wages over the 1980s, in contrast to the wage declines suffered by natives. These wage gains are largest for the most recent immigrant cohorts, as one would expect if assimilation were the underlying cause. Nevertheless, even Canadian and U.S. immigrants who arrived in the 1960s enjoyed wage gains relative to natives during 1980s, which suggests that in these countries wage assimilation continues well beyond an immigrant's first decade in his adopted homeland. This gradual and drawn out process of wage assimilation differs from the more sudden and discrete employment adjustment documented in Table 2.

Though informative, Tables 2 and 3 do not adjust for differences between groups or changes over time in age, education, geographic location, and other factors that might bias estimates of immigrant assimilation. The regression framework described in the previous section provides a convenient way to control for extraneous factors and also to synthesize the experiences of the various arrival cohorts over the 1980s into a single assimilation profile.

Table 4 presents selected coefficients from estimating equations (2) and (3) for 
employment. The dependent variable is a dummy identifying whether the individual was

employed during the census survey week. The coefficients were estimated by least squares,

and robust standard errors are shown in parentheses. In addition to the variables listed in Table

4, all regressions include controls for age and geographic location. ${ }^{17}$ Two specifications are

reported for each destination country. The first specification, in the columns labeled (1),

includes the independent variables mentioned so far, whereas the second specification, in the

columns labeled (2), also includes years of schooling as an additional independent variable. The

coefficients of the geographic controls are restricted to be the same for immigrants and natives,

but these coefficients can differ across survey years. ${ }^{18}$ The coefficients of the age and education

variables are allowed to vary both by nativity and survey year.

Table 4 reports the immigrant cohort and assimilation effects, as well as the period

effects, from the employment regressions. The estimated period effects, which are the

coefficients on the 1990/91 census dummy, repeat the message from Table 2 that employment

opportunities deteriorated between 1981 and 1991 in Australia and Canada and did not change

much in the United States over the same decade. ${ }^{19}$ The immigrant arrival cohort coefficients

\footnotetext{
${ }^{17}$ The age variables are dummies identifying five-year age groups from 30-34 through 55-59, with 25-29 yearolds as the omitted reference group. The geographic variables indicate region of residence within each destination country (with eight regions defined for Australia, six regions for Canada, and nine regions for the United States) and whether the individual lives in a metropolitan area.

${ }^{18}$ One motivation for restricting the coefficients of the geographic variables to be the same for immigrants and natives is that these variables are meant to capture temporal and regional variation in the cost-of-living and labor market conditions, factors which may impact immigrants and natives to a similar extent.

${ }^{19}$ Note that the coefficients on the 1990/91 census dummy become more negative in specification (2), which controls for years of schooling. This pattern arises because specification (2) allows the effect of schooling on employment to vary over time, and in all countries the estimated schooling effect is more positive in the later survey year. When calculated for an individual with the average level of schooling, the declines in native employment rates between 1980/81 and 1990/91 implied by specification (2) are similar to the coefficients on the 1990/91 census dummy in specification (1).
} 
reported in Table 4 have been normalized to represent immigrant-native employment differentials for men who are aged 25-29 (in both specifications) and who have 12 years of education in 1990/91 (in specification (2)). In addition, these differentials pertain to immigrants from the relevant arrival cohort when they have lived in the destination country for five years or less. For example, the estimated coefficient for 1976-80 Australian immigrants in column (1) indicates that, in their first five years after arriving, this cohort had an employment rate 14.5 percentage points below that of otherwise similar natives.

That the cohort coefficients are uniformly negative implies that, in all three countries, immigrants from every arrival period initially experienced lower employment than natives, but these employment deficits for new immigrants are much larger in Australia and the United States than in Canada. Within each country, the coefficients tend to be similar in magnitude for the various arrival cohorts. This finding suggests that, after controlling for years spent in the destination country, employment rates do not differ much across cohorts. The one important exception is the 1986-91 cohort of Canadian immigrants, whose employment rate is estimated to be permanently below that of other Canadian arrival cohorts by at least 6 percentage points.

We now turn to the assimilation effects that are the focus of our analysis. In Table 4, the coefficients of the "time in destination country" dummy variables indicate how employment rates change as an immigrant cohort becomes more familiar with its new surroundings. Australian and American immigrants display virtually identical patterns in which the bulk of employment assimilation takes place within the first decade after arrival. ${ }^{20}$ In both Australia and

\footnotetext{
${ }^{20}$ For the United States, several previous studies find this same pattern of immigrant employment adjustment. See Chiswick, Cohen, and Zach (1997) for men, Schoeni (1998) for women, and Funkhouser and Trejo
} 
the United States, employment rates shoot up by 10 percentage points as immigrants pass from 0-5 to 6-10 years in the destination country, but thereafter employment increases only modestly (2-4 percentage points) with further exposure to the host labor market.

Employment assimilation for Canadian immigrants, by contrast, is a much more continuous process that takes longer to play out. For example, according to the estimates that do not control for education (specification (1)), immigrant employment rates rise (relative to their level during the initial five years of Canadian residence) by 4 percentage points after 6-10 years, 6 percentage points after 11-15 years, 8 percentage points after 16-20 years, and 10 percentage points after more than 20 years in Canada. Despite the fact that employment assimilation beyond the first decade of residence is strongest for Canadian immigrants, the much greater initial adjustments of Australian and American immigrants result in total employment growth, even after more than 20 years of assimilation, that is larger in Australia and the United States (12-14 percentage points) than in Canada (9-10 percentage points).

Finally, recall the negative cohort coefficients discussed earlier. These coefficients indicate that, upon arrival, all immigrant cohorts had employment rates lower than those of comparable natives. Employment growth from assimilation, however, eventually erases all or most of this initial employment deficit for every immigrant arrival cohort. Consider, for example, the 1971-75 cohort of U.S. immigrants. According to the specification (1) estimates that do not control for education, during its first five years in the United States this cohort had an

(1998) for both genders. Funkhouser (2000) provides a detailed investigation of this phenomenon. Evidence for England (Wheatley Price 2001) and Denmark (Husted, Nielsen, Rosholm, and Smith 2001) also suggests that immigrant employment rates rise precipitously during the initial 5-10 years in the destination country. For Australia, McDonald and Worswick (1999b) report a similar finding for unemployment: the unemployment rates of immigrant men decline sharply, both in absolute terms and relative to native unemployment rates, during the first decade after arrival. 
employment rate 14 percentage points below that of natives. After just 6-10 years of U.S. residence, however, assimilation narrows the employment gap of this cohort by 10 percentage points, and after 20 years in the United States the cohort's employment rate closes to within a percentage point of the rate for comparable natives. Immigrants from other arrival cohorts and in other host countries display the same basic pattern. With sufficient time for adjustment, male immigrants in these three countries attain employment rates similar to those of natives. ${ }^{21}$

Table 5 presents analogous estimates for the wage data introduced in Table 3 . These $\log$ wage regressions are identical in structure to the employment regressions in Table 4, except that now the sample is restricted to employed men, and controls have been added for hours worked during the census survey week. These controls for weekly hours of work are included so that our estimates using the available information on weekly income (for Australia) or earnings (for Canada and the United States) more closely approximate the effects on hourly wages (i.e., the "price" of labor) that we seek. ${ }^{22}$ The coefficients of the weekly hours indicators are allowed to vary across census years but not by nativity.

Unlike in Table 3, where wages were adjusted for price differences across years, the dependent variables in Table 5 represent nominal wages. Therefore, the estimated period effects (i.e., the coefficients on the 1990/91 census dummy) reflect whatever inflation occurred during the 1980s, as well as the effects on real wages of any changes in national economic

\footnotetext{
${ }^{21}$ These comparisons ignore the fact that the regressions in Table 4 allow age effects to vary by nativity. The estimated age coefficients are roughly similar for natives and immigrants, however, so this general pattern of ultimate convergence in the employment rates of native-born and foreign-born men persists even when the comparisons account for differential age effects.

${ }^{22}$ For all three destination countries, the estimated patterns of immigrant wage assimilation are similar when we do not control for weekly hours of work. This suggests that assimilation in weekly earnings is driven by changes in hourly wages rather than by changes in weekly hours.
} 
conditions that took place over the decade. For each country, the coefficient of the 1990/91 census dummy becomes smaller when controls for education are added in specification (2). The explanation for this pattern is the same as that discussed earlier for the employment regressions (see footnote 19 above).

In Table 5, the estimated coefficients of the arrival cohort dummies reveal the extent of permanent wage differences between immigrant cohorts. Such wage differences are relatively modest in Australia and somewhat larger in Canada and the United States. Wage profiles tend to be lower for more recent arrival cohorts, especially in Canada and the United States. For example, in the specification (1) regression that does not control for education, Canadian immigrants arriving in 1986-91 have a permanent wage disadvantage of about 30 percent relative to their predecessors who arrived before 1970. The corresponding wage deficit is smaller but still sizeable for the most recent cohort of U.S. immigrants. The pattern in Table 5 of a steady decline in wages for successive cohorts of male immigrants to Canada and the United States confirms the findings of previous studies (e.g., Baker and Benjamin (1994) and Bloom, Grenier, and Gunderson (1995) for Canada, and Borjas $(1985,1995)$ and Funkhouser and Trejo (1998) for the United States).

The estimated coefficients of the "time in destination country" dummy variables measure wage growth due to immigrant assimilation. Consistent with earlier research by Borjas (1988) and McDonald and Worswick (1999a), we find no evidence of wage assimilation for Australian immigrants. Although both Canadian and U.S. immigrants enjoy significant wage boosts arising from increased exposure to the destination country's labor market, the magnitude and duration of such wage assimilation is greater in the United States. For example, without controlling for 
education, the estimates imply that wages grow by 11 percent as an immigrant cohort in Canada extends its time in the country from 0-5 to 11-15 years, but additional exposure to Canada beyond this point produces little wage improvement. For U.S. immigrants, the corresponding wage growth is 14 percent after 11-15 years in the country and 24 percent after 20 -plus years of residence. Estimates of immigrant wage assimilation and the pattern of differences across destination countries are similar in specification (2), which controls for education.

Given the estimates, from Tables 4 and 5, characterizing how immigrant employment and wage opportunities evolve with greater exposure to the host country, we can now proceed to implement equation (1). As discussed earlier, equation (1) decomposes the labor market assimilation of immigrants into employment and wage components, where each component is simply the percentage impact of assimilation on the relevant outcome. The log specification of the dependent variable in the wage regressions implies that the assimilation coefficients from these regressions already approximate percentage effects, but the corresponding coefficients in the employment regressions do not. We transform the estimated employment effects of assimilation into percentage terms by comparing these effects with the employment rates (reported in Table 2) of the most recent arrival cohort in the 1990/91 data.

For each destination country, Table 6 reports the resulting estimates of the components of equation (1), with standard errors in parentheses. The top panel of Table 6 presents estimates based on the regressions that do not control for education, whereas the bottom panel shows results from the alternative specification that conditions on education. As prescribed by equation (1), "total" immigrant earnings growth due to assimilation is computed as the sum of the estimates of earnings growth from employment assimilation and from wage assimilation. These 
calculations are reported for the assimilation-induced growth that occurs for an immigrant cohort between its first five years in the destination country and each of the durations of residence ranging from "6-10 years" to "more than 20 years." Finally, in order to highlight differences across countries in the nature of immigrant labor market adjustment, Table 6 also shows the percentage of total earnings growth from assimilation that arises from employment assimilation rather than from wage assimilation.

Initially consider the estimates in the top panel of Table 6, which do not control for education. Employment assimilation is an important contributor to immigrant earnings growth in all three countries, but the timing of this contribution varies. In Australia and the United States, the vast majority of immigrant employment assimilation occurs during the first decade after arrival, whereas employment rates for Canadian immigrants rise more continuously with duration of residence. In addition, the ultimate impact of employment assimilation is somewhat less in Canada than in the other two countries. After more than two decades in the destination country, employment assimilation increases immigrant earnings by about 17 percent in Australia and the United States and by 13 percent in Canada. Earnings growth from wage assimilation, on the other hand, is largest in the United States, sizeable in Canada, and zero or negative in Australia. Summing together the effects of employment and wage assimilation, earnings grow with duration of residence the most for U.S. immigrants and the least for Australian immigrants. After more than 20 years in the destination country, for example, total earnings growth from immigrant assimilation is 40 percent in the United States, 25 percent in Canada, and 8 percent in Australia.

How does labor market flexibility affect the nature of immigrant earnings assimilation? 
This question motivates our study, and we hope to learn something about the answer by comparing across host countries the relative importance of employment versus wage adjustments in accounting for total earnings growth from immigrant assimilation. Because Australian immigrants experience no wage assimilation, immigrant earnings growth in Australia comes entirely from employment gains. The top panel of Table 6 shows that, at almost any duration of residence, the earnings growth of Canadian immigrants derives in roughly equal parts from employment assimilation and from wage assimilation. For Canadian immigrants, employment and wages rise at about the same rate with greater exposure to their adopted country. For U.S. immigrants, however, wage assimilation proceeds continuously but employment gains are concentrated in the first decade after arrival. As a result, for the United States, the share of immigrant earnings growth attributable to employment assimilation falls from 71 percent after 6-10 years of residence to 41 percent after more than 20 years of residence. For the first 15 years after arrival, employment adjustments account for a larger share of immigrant earnings growth in the United States than in Canada, but the opposite pattern emerges at longer durations of residence.

The estimates in the top panel of Table 6 are consistent with our discussion in Section II about how labor market rigidities might influence immigrant assimilation. Relatively inflexible wages in Australia suggest that immigrants there might improve themselves primarily though employment gains rather than wage growth, and we find empirically that employment gains explain all of the labor market progress experienced by Australian immigrants. Wages are less rigid in Canada and the United States than in Australia, with the general consensus being that the U.S. labor market is the most flexible of the three. We find that wage assimilation is an 
important source of immigrant earnings growth in both Canada and the United States, but the magnitude of wage assimilation is always substantially larger in the United States. For example, the assimilation associated with 16-20 years of residence in the destination country raises immigrant wages by 9 percent in Canada compared to 16 percent in the United States. Moreover, for sufficiently long periods of adjustment (at least 15 years), the share of immigrant earnings growth due to wage assimilation rather than employment assimilation is also larger in the United States.

The bottom panel of Table 6 reports analogous estimates that control for education. Overall, the patterns are very similar to those just described for the top panel of Table 6 . For Canada and the United States, controlling for education generates somewhat lower estimates of immigrant employment assimilation and the share of total earnings growth arising from employment assimilation, but the comparisons across countries remain as described above.

\section{Robustness}

This section explores the sensitivity of our findings to two potentially important critiques. One such critique is that Australia, Canada, and the United States differ markedly in the source country composition of their immigrant flows (Reitz 1998; Antecol, Cobb-Clark, and Trejo 2003), and national origins often exert a strong influence on immigrant outcomes. In particular, Borjas (1993) and Antecol, Cobb-Clark, and Trejo (2003) show that the skill deficit for U.S. immigrants relative to Australian and Canadian immigrants arises primarily because the United States receives a much larger share of immigrants from Latin America than do the other two countries. Consequently, an important concern is whether differences in national origins drive 
the cross-country patterns of immigrant assimilation that we observe.

To investigate this issue, we replicated our analyses for two subsamples of the immigrant population that are fairly homogeneous in national origins yet still provide sufficiently large sample sizes for each country. In Tables 7-9, we report results when the immigrant samples include only men born in Europe (the left three columns of Tables 7-8 and the top panel of Table 9) and when the immigrant samples include only men born in Asia (the right three columns of Tables 7-8 and the bottom panel of Table 9). In both sets of analyses, the native samples remain the same as before (i.e., the same as in Tables 4-6). For brevity, we present only estimates from the specification that does not control for education; estimates that condition on education are similar.

In general, the patterns for European and Asian immigrants considered separately are similar to those discussed previously for immigrants from all source countries combined. Not surprisingly, however, estimates for particular national origin groups are less precise than the corresponding estimates for all immigrants combined. Standard errors are particularly large for Asian immigrants in Australia and Canada. Nonetheless, we still find that, regardless of national origin, employment growth drives immigrant earnings assimilation in Australia, whereas wage growth plays an important and often leading role for Canadian and American immigrants. Furthermore, the amount of assimilation-induced wage growth experienced by European or Asian immigrants tends to be highest in the United States, and, after at least 15 years in the destination country, the share of total earnings growth for these immigrants that derives from wage assimilation rather than employment assimilation also tends to be highest in the United States. 
Despite the similar patterns across countries noted above, European and Asian immigrants show some interesting differences in their patterns of labor market adjustment within a particular country. In Australia, for example, Asian immigrants experience positive wage growth from assimilation (exceeding 10 percent after 15 years of residence), whereas European immigrants do not. In all three countries, initial employment and wage deficits (relative to natives) are larger for Asian immigrants than for European immigrants, but assimilation tends to produce more rapid employment and wage growth for Asians. ${ }^{23}$ Consider, for example, the 1976-80 cohort of U.S. immigrants. Upon arrival, European immigrants from this cohort had an employment rate about 7 percentage points below that of U.S. natives, whereas Asian immigrants from the same cohort suffered a much larger initial employment gap of 22 percentage points (Table 7). The corresponding wage deficits upon entry were 7 percent for Europeans and 26 percent for Asians (Table 8). With 11-15 years of assimilation in the destination country, however, the estimates imply that employment rates improve by 7 percentage points for Europeans and by 17 percentage points for Asians, and that wages grow by 14 percent for Europeans and by 29 percent for Asians. Consequently, for this particular cohort of European and Asian immigrants to the United States, all or most of the sizeable initial employment and wage gaps relative to natives were erased after 11-15 years of U.S. residence.

Concerning the total earnings growth associated with immigrant assimilation, Table 9 indicates that for European immigrants such earnings growth is similar in Canada and the United States (exceeding 30 percent after 20-plus years in the destination country) and dramatically

\footnotetext{
${ }^{23}$ Consistent with our results in Table 7 regarding employment rates, McDonald and Worswick (1999b) find that Asian immigrants experience particularly high rates of unemployment when they initially enter Australia, but Asian
} 
lower in Australia (less than 10 percent after 20-plus years). For Asian immigrants, Table 9 shows that total earnings growth from assimilation is highest in the United States (77 percent after 20-plus years) and similar in Australia and Canada (around 35 percent after 20-plus years).

A second critique of our results stems from the fact that universities in Australia, Canada, and the United States host a sizeable number of foreign undergraduate and graduate students who typically return to their home countries after completing their studies. Return migration by these foreign students could cause immigrant employment rates to rise sharply after an arrival cohort has spent 5-10 years in the destination country, even if employment rates were stable for non-students in the cohort who did not return home. More generally, the presence of temporary immigrants such as foreign students in our samples can bias estimates of assimilation profiles, and the magnitude (or even the direction) of this bias might vary across destination countries. To explore this issue, we redid our analyses after dropping from the samples anyone currently enrolled in school. Excluding students does not materially affect the estimates of immigrant wage assimilation in any of the destination countries, nor does it change the estimates of employment assimilation in Australia and the Canada. For the United States, however, dropping students yields a pattern of employment adjustment that is qualitatively similar but somewhat more attenuated than what we saw in Table 4. In particular, the assimilation-induced jump in immigrant employment rates during their first decade in the United States is now only 6 percentage points instead of 10 percentage points. But it is still the case that, after this initial jump, further employment assimilation is minimal (about 2 percentage points). Consequently, 
when we exclude students, the only important change in our estimates is less employment growth for U.S. immigrants. This change strengthens our main finding that wage growth accounts for a larger share of immigrant earnings assimilation in the United States than in Australia or Canada. $^{24}$

\section{Conclusion}

As sparsely-populated, English-speaking countries in which immigration has always been an important source of demographic change, Australia and Canada share many social and economic features with the United States. Late twentieth-century immigrants to Australia, however, were entitled to unemployment compensation on arrival, and they faced a much more compressed wage distribution than immigrants to the United States. As a host for immigrants, Canada falls somewhere between these two extremes, though it is probably more similar to the United States than to Australia. Simple economic reasoning would then lead one to expect that new immigrants to Australia would spend more time unemployed, earn higher wages (relative to natives) when employed, and invest less in skills that foster wage growth than immigrants to the United States, and that Canadian immigrants would occupy a middle ground.

In this paper we generate estimates of employment and wage assimilation among immigrants to these three countries using census data spanning the decade of the 1980s. Our empirical results largely confirm our expectations. Wage assimilation is greatest in the United States and least in Australia. Employment assimilation constitutes the largest share of total

\footnotetext{
${ }^{24}$ Although excluding individuals enrolled in school may reduce biases arising from the return migration of foreign students, this approach could also miss legitimate facets of immigrant assimilation that involve acquiring additional schooling and educational certification in the destination country. Indeed, there is evidence that postmigration investments in education are substantial for adult immigrants to Australia (Chiswick and Miller 1994) and the United States (Khan 1997; Betts and Lofstrom 2000). Here, we are not arguing that excluding students produces better
} 
earnings assimilation in Australia — in fact it is the sole source of earnings growth there - and the smallest share in the United States. Of course, it is certainly possible that these dramatic international differences in immigrant assimilation derive from idiosyncrasies of the countries other than the labor market institutions that we emphasize. After all, with only three countries, we have very few degrees of freedom which to distinguish among alternative hypotheses. Nonetheless, our results are consistent with the hypothesis that national labor market institutions - in particular those that influence the dispersion of wages and the incomes of the unemployed — can play a key role in the immigrant assimilation process. 


\section{References}

Abowd, John M., Francis Kramarz, Thomas Lemieux and David N. Margolis. "Minimum Wages and Youth Employment in France and the United States", in David Blanchflower and Richard B. Freeman, eds. Youth Employment and Joblessness in Advanced Countries. Chicago: University of Chicago Press, 2000.

Angrist, Joshua D., and Kugler, Adriana D. "Protective or Counter-Productive? Labour Market Institutions and the Effect of Immigration on EU Natives." Economic Journal, June 2003, 113 , pp. F302-F331.

Antecol, Heather, Deborah A. Cobb-Clark, and Stephen J. Trejo. "Immigration Policy and the Skills of Immigrants to Australia, Canada, and the United States." Journal of Human Resources, Winter 2003, 38(1), pp. 192-218.

Baker, Michael, and Benjamin, Dwayne. "The Performance of Immigrants in the Canadian Labor Market." Journal of Labor Economics, July 1994, 12(3), pp. 369-405.

Bell, Linda A. and Richard B. Freeman. "The Incentive for Working Hard: Explaining Hours Worked Differences between the U.S. and Germany”. Labour Economics 8(2) (May 2001): 181-202.

Bertola, Giuseppe and Richard Rogerson. "Institutions and Labor Reallocation". European Economic Review 41(6) (1997): 937-957.

Betts, Julian R., and Lofstrom, Magnus. "The Educational Attainment of Immigrants: Trends and Implications." In George J. Borjas, ed., Issues in the Economics of Immigration. Chicago: University of Chicago Press, 2000, pp. 51-115.

Blau, Francine D., and Lawrence M. Kahn. "International Differences in Male Wage Inequality: Institutions versus Market Forces." Journal of Political Economy. August 1996; 104(4): 791-836.

Blau, Francine D., and Lawrence M. Kahn. "Gender Differences in Pay". Journal of Economic Perspectives (Fall 2000): 14(4): 75-99

Bloom, David E.; Grenier, Gilles; and Gunderson, Morley. "The Changing Labour Market Position of Canadian Immigrants." Canadian Journal of Economics, November 1995, 28(4b), pp. 9871005 .

Borjas, George J. 1985. "Assimilation, Changes in Cohort Quality, and the Earnings of Immigrants." Journal of Labor Economics 3(4): 463-89.

1988. International Differences in the Labor Market Performance of Immigrants. Kalamazoo, Mich.: W.E. Upjohn Institute for Employment Research.

"Immigration Policy, National Origin, and Immigrant Skills: A Comparison of Canada and the United States." In Small Differences That Matter: Labor Markets and Income Maintenance in Canada and the United States, edited by David Card and Richard B. Freeman. Chicago: University of Chicago Press, 1993, pp. 21-43. 
1995. "Assimilation and Changes in Cohort Quality Revisited: What Happened to Immigrant Earnings in the 1980s?" Journal of Labor Economics 13(2): 201-45.

Butcher, Kristin F. and John DiNardo. "The Immigrant and Native-born Wage Distributions: Evidence from United States Censuses" National Bureau of Economic Research Working Paper: 6630 June 1998

Card, David; Kramarz, Francis; and Lemieux, Thomas. "Changes in the Relative Structure of Wages and Employment: A Comparison of the United States, Canada, and France." Canadian Journal of Economics, August 1999, 32(4), pp. 843-77.

Chiswick, Barry R. 1978. "The Effect of Americanization on the Earnings of Foreign-Born Men." Journal of Political Economy 86(5): 897-921.

Chiswick, Barry R.; Cohen, Yinon; and Zach, Tzippi. "The Labor Market Status of Immigrants: Effects of the Unemployment Rate at Arrival and Duration of Residence." Industrial and Labor Relations Review, January 1997, 50(2), pp. 289-303.

Chiswick, Barry R., and Miller, Paul W. "The Determinants of Post-Immigration Investments in Education.” Economics of Education Review, June 1994, 13(2), pp. 163-77.

DiNardo, John, Nicole M. Fortin and Thomas Lemieux, "Labor Market Institutions and the Distribution of Wages, 1973-1992: A Semiparametric Approach" Econometrica 64(5) (September 1996): 1001-44

Friedberg, Rachel M. 1991. "The Labor Market Assimilation of Immigrants in the United States: The Role of Age at Arrival.” Boston: Massachusetts Institute of Technology. Mimeo.

Funkhouser, Edward. "Convergence in Employment Rates of Immigrants." In George J. Borjas, ed., Issues in the Economics of Immigration. Chicago: University of Chicago Press, 2000.

Funkhouser, Edward; and Trejo, Stephen J. "Labor Market Outcomes of Female Immigrants in the United States." In James P. Smith and Barry Edmonston, eds., The Immigration Debate: Studies on the Economic, Demographic, and Fiscal Effects of Immigration. Washington, DC: National Academy Press, 1998, pp. 239-88.

Harris, John R. and Michael P. Todaro. "Migration, Unemployment \& Development: A Two-Sector Analysis" American Economic Review 60(1) (March 1970) 126-42.

Husted, Leif; Nielsen, Helena S.; Rosholm, Michael; and Smith, Nina. "Employment and Wage Assimilation of Male First-Generation Immigrants in Denmark." International Journal of Manpower, 2001, 22(1/2), pp. 39-68.

Khan, Aliya Hashmi. "Post-Migration Investment in Education by Immigrants in the United States." Quarterly Review of Economics and Finance 37, 1997, 37, pp. 285-313.

Kossoudji, Sherrie A. 1989. "Immigrant Worker Assimilation: Is It a Labor Market Phenomenon?" Journal of Human Resources 24(3): 494-527.

Kuhn, Peter. "Summary and Synthesis", in P. Kuhn, ed. Losing Work, Moving On: International 
Perspectives on Worker Displacement. Kalamazoo, Michigan: W. E. Upjohn Institute for Employment Research, 2002.

Lubotsky, Darren. "The Effect of Changes in the U.S. Wage Structure on Recent Immigrants' Earnings" Princeton University, Industrial Relations Section working paper no. 458, September 2001.

McDonald, James T., and Christopher Worswick. 1997. "Unemployment Incidence of Immigrant Men in Australia" Canadian Public Policy 23(4): 353-373.

. 1999a. "The Earnings of Immigrant Men in Australia: Assimilation, Cohort Effects, and Macroeconomic Conditions." Economic Record 75(228): 49-62.

1999b. "Immigrant Assimilation in a Regulated Labour Market: Unemployment of Immigrant Men in Australia." Hobart: University of Tasmania. Mimeo.

2000. "Earnings and Employment Probabilities of Men by Education and Birth Cohort, 1982-96: Evidence for the United States, Canada and Australia." Hobart: University of Tasmania. Mimeo.

Miller, Paul and Leanne Neo. 2001. "Labor Market Flexibility and Immigrant Adjustment.” Perth: University of Western Australia. Mimeo.

Moene, Karl Ove and Michael Wallerstein. "Pay Inequality" Journal of Labor Economics 15(3.1) (July 1997): 403-430.

OECD. The OECD Jobs Study: Evidence and Explanations, Part II, The Adjustment Potential of the Labour Market. Paris: OECD, 1994.

OECD. Employment Outlook, 1996 and 1997.

Reitz, Jeffrey G. Warmth of the Welcome: The Social Causes of Economic Success for Immigrants in Different Nations and Cities. Boulder, Colo.: Westview Press, 1998.

Schoeni, Robert. "Labor Market Assimilation of Immigrant Women.” Industrial and Labor Relations Review, April 1998, 51(3), pp. 483-504

Wheatley Price, Stephen. "The Employment Adjustment of Male Immigrants in England." Journal of Population Economics, 2001, 14(1), pp. 193-220. 
Table 1: Institutional Differences Among Australia, Canada, and the United States

\author{
A. Indicators of Union Power \\ 1. Density (\%) \\ 2. Coverage (\%) \\ 3. Centralization (ranking) \\ 4. Co-ordination 1980 (ranking)
}

B. Indicators of Wage Dispersion

1. $90 / 10$ wage ratio, men

2. $90 / 50$ wage ratio, men

3. $50 / 10$ wage ratio, men

4. Standard deviation of log wages

\section{Indicators of Income Support}

1. UI Benefit Replacement Rate Index (\%)

\begin{tabular}{cc}
\multicolumn{2}{c}{ Australia } \\
$\mathbf{1 9 8 0}$ & $\mathbf{1 9 9 0}$ \\
48 & 41 \\
88 & 80 \\
3 & 1 \\
7 & 5
\end{tabular}

\section{Canada}

19801990

36

37

17

18

$\begin{array}{ll}2.67 & 3.93 \\ 1.78 & 2.00 \\ 1.50 & 1.96 \\ .499 & .596\end{array}$

3.73

4.21

1.82

2.10

2.31

.797

.684

24

26

25

28

\begin{tabular}{ccc}
$\mathbf{1 9 9 0}$ & \multicolumn{2}{c}{ United States } \\
\cline { 3 - 3 } 36 & $\mathbf{1 9 8 0}$ & $\mathbf{1 9 9 0}$ \\
38 & 22 & 16 \\
17 & 17 & 18 \\
17 & 18 & 17
\end{tabular}

\section{Notes:}

Rankings of bargaining centralization and co-ordination are among 19 OECD countries; 1 is highest, ties allowed. Australian wage data refer to weekly income of employees.

Canadian and U.S. wage data refer to weekly earnings of employees.

UI replacement rate index is an average of replacement rates for two earnings levels, three family situations, and three durations of unemployment, computed by OECD.

\section{Sources:}

Union data from OECD, Employment Outlook, July 1997, Table 3.3.

Wage data from the 1981 and 1991 Australian and Canadian censuses and the 1980 and 1990 U.S. census. Sample is restricted to employed, white native-born men aged 25-59.

UI replacement rate index is from OECD Employment Outlook, July1996, Chart 2.2 (numerical rates estimated from graph). 
Table 2

Employment Rates

\begin{tabular}{|c|c|c|c|c|c|c|}
\hline \multirow{3}{*}{ Natives } & \multicolumn{2}{|c|}{ Australia } & \multicolumn{2}{|c|}{ Canada } & \multicolumn{2}{|c|}{ United States } \\
\hline & 1981 & 1991 & 1981 & 1991 & 1980 & 1990 \\
\hline & $\begin{array}{c}92.3 \\
(0.2) \\
{[17,180]}\end{array}$ & $\begin{array}{c}86.1 \\
(0.2) \\
{[22,336]}\end{array}$ & $\begin{array}{c}89.2 \\
(0.1) \\
{[75,355]}\end{array}$ & $\begin{array}{c}85.7 \\
(0.09) \\
{[137,349]}\end{array}$ & $\begin{array}{c}89.4 \\
(0.2) \\
{[36,908]}\end{array}$ & $\begin{array}{c}88.9 \\
(0.2) \\
{[43,052]}\end{array}$ \\
\hline All Immigrants & $\begin{array}{c}87.5 \\
(0.5) \\
{[5,136]}\end{array}$ & $\begin{array}{c}80.4 \\
(0.4) \\
{[8,012]}\end{array}$ & $\begin{array}{c}91.7 \\
(0.2) \\
{[18,535]}\end{array}$ & $\begin{array}{c}83.0 \\
(0.2) \\
{[28,538]}\end{array}$ & $\begin{array}{c}86.2 \\
(0.09) \\
{[140,999]}\end{array}$ & $\begin{array}{c}85.4 \\
(0.08) \\
{[211,220]}\end{array}$ \\
\hline $\begin{array}{l}\text { Immigrant Arriv } \\
\text { Pre-1961 }\end{array}$ & & & $\begin{array}{c}91.5 \\
(0.3) \\
{[6,863]}\end{array}$ & $\begin{array}{c}80.0 \\
(0.7) \\
{[3,036]}\end{array}$ & $\begin{array}{c}87.5 \\
(0.2) \\
{[32,994]}\end{array}$ & $\begin{array}{c}83.1 \\
(0.4) \\
{[10,870]}\end{array}$ \\
\hline $1961-65$ & & & $\begin{array}{c}93.6 \\
(0.6) \\
{[1,722]}\end{array}$ & $\begin{array}{c}84.9 \\
(0.8) \\
{[1,829]}\end{array}$ & $\begin{array}{c}91.0 \\
(0.2) \\
{[15,350]}\end{array}$ & $\begin{array}{c}87.3 \\
(0.3) \\
{[10,425]}\end{array}$ \\
\hline $1966-70$ & & & $\begin{array}{c}94.4 \\
(0.4) \\
{[3,765]}\end{array}$ & $\begin{array}{c}88.8 \\
(0.5) \\
{[4,508]}\end{array}$ & $\begin{array}{c}90.6 \\
(0.2) \\
{[23,292]}\end{array}$ & $\begin{array}{c}88.2 \\
(0.2) \\
{[16,851]}\end{array}$ \\
\hline Pre-1971 & $\begin{array}{c}89.0 \\
(0.5) \\
{[3,430]}\end{array}$ & $\begin{array}{c}81.5 \\
(0.6) \\
{[3,647]}\end{array}$ & & & & \\
\hline $1971-75$ & $\begin{array}{l}90.0 \\
(1.0) \\
{[858]}\end{array}$ & $\begin{array}{c}83.4 \\
(1.3) \\
{[842]}\end{array}$ & $\begin{array}{c}91.4 \\
(0.5) \\
{[3,769]}\end{array}$ & $\begin{array}{c}88.4 \\
(0.5) \\
{[5,040]}\end{array}$ & $\begin{array}{c}88.7 \\
(0.2) \\
{[31,844]}\end{array}$ & $\begin{array}{c}88.6 \\
(0.2) \\
{[26,339]}\end{array}$ \\
\hline $1976-80$ & $\begin{array}{l}79.4 \\
(1.4) \\
{[848]}\end{array}$ & $\begin{array}{c}84.0 \\
(1.3) \\
{[745]}\end{array}$ & $\begin{array}{c}86.8 \\
(0.7) \\
{[2,416]}\end{array}$ & $\begin{array}{c}86.9 \\
(0.5) \\
{[3,964]}\end{array}$ & $\begin{array}{c}78.2 \\
(0.2) \\
{[37,519]}\end{array}$ & $\begin{array}{c}89.0 \\
(0.2) \\
{[37,239]}\end{array}$ \\
\hline $1981-85$ & & $\begin{array}{c}80.9 \\
(1.2) \\
{[1,019]}\end{array}$ & & $\begin{array}{c}83.7 \\
(0.6) \\
{[3,562]}\end{array}$ & & $\begin{array}{c}86.8 \\
(0.1) \\
{[56,349]}\end{array}$ \\
\hline $1986-91$ & & $\begin{array}{c}74.7 \\
(1.0) \\
{[1,759]}\end{array}$ & & $\begin{array}{c}73.2 \\
(0.5) \\
{[6,599]}\end{array}$ & & $\begin{array}{c}78.9 \\
(0.2) \\
{[53,147]}\end{array}$ \\
\hline
\end{tabular}

Note: The reported statistics give the percentage of individuals who were employed during the census survey week, with standard errors shown in parentheses and cell sample sizes in brackets. The samples include men ages 25-59, with non-whites excluded from the native but not the foreignborn samples. The intervals listed above for the immigrant arrival cohorts are those defined in the Australian and Canadian data; the slightly different immigrant cohorts defined in the U.S. data are as follows: pre-1960, 1960-64, 1965-69, 1970-74, 1975-79, 1980-84, and 1985-90. 
Table 3

Mean Log Wages

\begin{tabular}{|c|c|c|c|c|c|c|}
\hline & & & & & Unit & States \\
\hline & 1981 & 1991 & 1981 & 1991 & 1980 & 1990 \\
\hline Natives & $\begin{array}{c}6.297 \\
(0.004) \\
{[15,299]}\end{array}$ & $\begin{array}{c}6.270 \\
(0.004) \\
{[17,958]}\end{array}$ & $\begin{array}{c}6.507 \\
(0.003) \\
{[65,119]}\end{array}$ & $\begin{array}{c}6.452 \\
(0.002) \\
{[114,079]}\end{array}$ & $\begin{array}{c}6.350 \\
(0.004) \\
{[32,490]}\end{array}$ & $\begin{array}{c}6.313 \\
(0.004) \\
{[37,653]}\end{array}$ \\
\hline All Immigrants & $\begin{array}{c}6.272 \\
(0.007) \\
{[4,338]}\end{array}$ & $\begin{array}{c}6.267 \\
(0.007) \\
{[5,995]}\end{array}$ & $\begin{array}{c}6.506 \\
(0.005) \\
{[16,272]}\end{array}$ & $\begin{array}{c}6.406 \\
(0.006) \\
{[22,303]}\end{array}$ & $\begin{array}{c}6.186 \\
(0.002) \\
{[116,985]}\end{array}$ & $\begin{array}{c}6.077 \\
(0.002) \\
{[172,871]}\end{array}$ \\
\hline $\begin{array}{l}\text { Immigrant Arri } \\
\text { Pre-1961 }\end{array}$ & & & $\begin{array}{c}6.575 \\
(0.008) \\
{[6,080]}\end{array}$ & $\begin{array}{c}6.522 \\
(0.016) \\
{[2,343]}\end{array}$ & $\begin{array}{c}6.427 \\
(0.004) \\
{[28,178]}\end{array}$ & $\begin{array}{c}6.453 \\
(0.008) \\
{[8,799]}\end{array}$ \\
\hline $1961-65$ & & & $\begin{array}{c}6.546 \\
(0.018) \\
{[1,562]}\end{array}$ & $\begin{array}{c}6.565 \\
(0.022) \\
{[1,497]}\end{array}$ & $\begin{array}{c}6.358 \\
(0.006) \\
{[13,657]}\end{array}$ & $\begin{array}{c}6.450 \\
(0.008) \\
{[8,868]}\end{array}$ \\
\hline 1966-70 & & & $\begin{array}{c}6.575 \\
(0.011) \\
{[3,471]}\end{array}$ & $\begin{array}{c}6.595 \\
(0.013) \\
{[3,888]}\end{array}$ & $\begin{array}{c}6.251 \\
(0.005) \\
{[20,553]}\end{array}$ & $\begin{array}{c}6.383 \\
(0.007) \\
{[14,496]}\end{array}$ \\
\hline Pre-1971 & $\begin{array}{c}6.261 \\
(0.009) \\
{[2,942]}\end{array}$ & $\begin{array}{c}6.290 \\
(0.011) \\
{[2,771]}\end{array}$ & & & & \\
\hline $1971-75$ & $\begin{array}{c}6.308 \\
(0.016) \\
{[753]}\end{array}$ & $\begin{array}{c}6.275 \\
(0.022) \\
{[652]}\end{array}$ & $\begin{array}{c}6.410 \\
(0.012) \\
{[3,344]}\end{array}$ & $\begin{array}{c}6.499 \\
(0.013) \\
{[4,337]}\end{array}$ & $\begin{array}{c}6.060 \\
(0.005) \\
{[27,442]}\end{array}$ & $\begin{array}{c}6.257 \\
(0.005) \\
{[22,687]}\end{array}$ \\
\hline $1976-80$ & $\begin{array}{c}6.281 \\
(0.020) \\
{[643]}\end{array}$ & $\begin{array}{c}6.275 \\
(0.025) \\
{[589]}\end{array}$ & $\begin{array}{c}6.281 \\
(0.017) \\
{[1,815]}\end{array}$ & $\begin{array}{c}6.416 \\
(0.014) \\
{[3,336]}\end{array}$ & $\begin{array}{c}5.926 \\
(0.005) \\
{[27,175]}\end{array}$ & $\begin{array}{c}6.133 \\
(0.004) \\
{[32,182]}\end{array}$ \\
\hline $1981-85$ & & $\begin{array}{c}6.234 \\
(0.019) \\
{[764]}\end{array}$ & & $\begin{array}{c}6.286 \\
(0.016) \\
{[2,842]}\end{array}$ & & $\begin{array}{c}5.924 \\
(0.003) \\
{[47,233]}\end{array}$ \\
\hline 1986-91 & & $\begin{array}{c}6.227 \\
(0.017) \\
{[1,219]}\end{array}$ & & $\begin{array}{c}6.075 \\
(0.015) \\
{[4,060]}\end{array}$ & & $\begin{array}{c}5.826 \\
(0.004) \\
{[38,606]}\end{array}$ \\
\hline
\end{tabular}

Note: The reported statistics are averages of the natural logarithm of weekly personal income (for Australia) or weekly earnings (for Canada and the United States), with standard errors shown in parentheses and cell sample sizes in brackets. To facilitate comparisons across years within each country, figures have been converted to 1990 dollars for Australia and Canada and to 1989 dollars for the United States. The samples include employed men ages 25-59, with non-whites excluded from the native but not the foreign-born samples. The intervals listed above for the immigrant arrival cohorts are those defined in the Australian and Canadian data; the slightly different immigrant cohorts defined in the U.S. data are as follows: pre-1960, 1960-64, 1965-69, 1970-74, 1975-79, 1980-84, and 1985-90. 
Table 4

Employment Regressions

Assimilation, Cohort and Period Effects

\begin{tabular}{|c|c|c|c|c|c|c|}
\hline \multirow[b]{2}{*}{$\underline{\text { Regressor }}$} & \multicolumn{2}{|c|}{ Australia } & \multicolumn{2}{|c|}{ Canada } & \multicolumn{2}{|c|}{ United States } \\
\hline & $(1)$ & $(2)$ & $(1)$ & $(2)$ & $(1)$ & $(2)$ \\
\hline \multicolumn{7}{|c|}{ Time in Destination Country: } \\
\hline \multirow[t]{2}{*}{ 6-10 Years } & .101 & .099 & .039 & .031 & .099 & .100 \\
\hline & $(.029)$ & $(.029)$ & $(.016)$ & $(.016)$ & $(.006)$ & $(.006)$ \\
\hline \multirow[t]{2}{*}{ 11-15 Years } & .112 & .120 & .060 & .055 & .113 & .110 \\
\hline & $(.023)$ & $(.025)$ & $(.012)$ & $(.013)$ & $(.005)$ & $(.005)$ \\
\hline \multirow[t]{2}{*}{ 16-20 Years } & .121 & .130 & .083 & .070 & .115 & .113 \\
\hline & $(.027)$ & $(.029)$ & $(.017)$ & $(.019)$ & $(.007)$ & $(.008)$ \\
\hline \multirow[t]{2}{*}{ More than 20 Years } & .126 & .140 & .096 & .086 & .130 & .122 \\
\hline & $(.031)$ & $(.033)$ & $(.019)$ & $(.021)$ & $(.009)$ & $(.010)$ \\
\hline \multicolumn{7}{|l|}{ Immigrant Arrival Cohort: } \\
\hline \multirow[t]{2}{*}{ Pre-1961 } & & & -.069 & -.023 & -.160 & -.118 \\
\hline & & & $(.021)$ & $(.027)$ & $(.010)$ & $(.013)$ \\
\hline \multirow[t]{2}{*}{$1961-65$} & & & -.060 & -.014 & -.141 & -.103 \\
\hline & & & $(.019)$ & $(.024)$ & $(.009)$ & $(.011)$ \\
\hline \multirow[t]{2}{*}{$1966-70$} & & & -.044 & -.011 & -.147 & -.107 \\
\hline & & & $(.016)$ & $(.021)$ & $(.007)$ & $(.010)$ \\
\hline \multirow[t]{2}{*}{ Pre-1971 } & -.150 & -.168 & & & & \\
\hline & $(.029)$ & $(.038)$ & & & & \\
\hline \multirow[t]{2}{*}{$1971-75$} & -.147 & -.161 & -.054 & -.017 & -.141 & -.101 \\
\hline & $(.030)$ & $(.036)$ & $(.017)$ & $(.020)$ & $(.007)$ & $(.009)$ \\
\hline \multirow[t]{2}{*}{$1976-80$} & -.145 & -.164 & -.054 & -.026 & -.140 & -.103 \\
\hline & $(.018)$ & $(.026)$ & $(.009)$ & $(.012)$ & $(.004)$ & $(.006)$ \\
\hline \multirow[t]{2}{*}{$1981-85$} & -.167 & -.172 & -.065 & -.037 & -.146 & -.113 \\
\hline & $(.033)$ & $(.035)$ & $(.018)$ & $(.019)$ & $(.007)$ & $(.008)$ \\
\hline \multirow[t]{2}{*}{$1986-91$} & -.125 & -.140 & -.130 & -.110 & -.124 & -.094 \\
\hline & $(.017)$ & $(.018)$ & $(.008)$ & $(.009)$ & $(.004)$ & $(.004)$ \\
\hline \multirow[t]{2}{*}{ 1990/91 Census Dummy } & -.086 & -.188 & -.053 & -.128 & .008 & -.017 \\
\hline & $(.010)$ & $(.019)$ & $(.004)$ & $(.007)$ & $(.006)$ & $(.007)$ \\
\hline $\mathrm{R}^{2}$ & .033 & .045 & .033 & .059 & .024 & .034 \\
\hline Controls for Education & No & Yes & No & Yes & No & Yes \\
\hline
\end{tabular}

Note: The dependent variable is a dummy identifying whether the individual was employed during the census survey week. The coefficients were estimated by least squares, and robust standard errors are shown in parentheses. Data are from the 1981 and 1991 Australian and Canadian censuses and the 1980 and 1990 U.S. censuses. The samples include men ages 25-59, with non-whites excluded from the native but not the foreign-born samples. The sample sizes for these regressions are 52,664 for Australia, 259,777 for Canada, and 432,179 for the United States. In addition to the variables listed above, all regressions include indicators for age and geographic location. The coefficients of the geographic controls are restricted to be the same for immigrants and natives, but these coefficients can differ across census years. The coefficients of the age and education variables are allowed to vary both by nativity and census year. The reference group for the "time in destination country" dummies is 0-5 years. The intervals listed above for the immigrant arrival cohorts are those defined in the Australian and Canadian data; the slightly different immigrant cohorts defined in the U.S. data are as follows: pre-1960, 1960-64, 1965-69, 1970-74, 1975-79, 1980-84, and 1985-90. The immigrant cohort coefficients reported in this table have been normalized to represent immigrant-native employment differentials for men who are aged 25-29 (in both specifications) and who have 12 years of education in 1990/91 (in specification (2)). 
Table 5

Wage Regressions

Assimilation, Cohort and Period Effects

\begin{tabular}{|c|c|c|c|c|c|c|}
\hline \multirow[b]{2}{*}{$\underline{\text { Regressor }}$} & \multicolumn{2}{|c|}{ Australia } & \multicolumn{2}{|c|}{ Canada } & \multicolumn{2}{|c|}{ United States } \\
\hline & $(1)$ & $(2)$ & $(1)$ & $(2)$ & $(1)$ & $(2)$ \\
\hline \multicolumn{7}{|c|}{ Time in Destination Country: } \\
\hline \multirow[t]{2}{*}{ 6-10 Years } & .032 & .009 & .046 & .052 & .052 & .070 \\
\hline & $(.047)$ & $(.046)$ & $(.043)$ & $(.042)$ & $(.017)$ & $(.015)$ \\
\hline \multirow[t]{2}{*}{ 11-15 Years } & -.063 & -.086 & .111 & .139 & .144 & .183 \\
\hline & $(.037)$ & $(.039)$ & $(.028)$ & $(.031)$ & $(.011)$ & $(.012)$ \\
\hline \multirow[t]{2}{*}{$16-20$ Years } & -.061 & -.087 & .094 & .115 & .158 & .203 \\
\hline & $(.044)$ & $(.046)$ & $(.045)$ & $(.047)$ & $(.018)$ & $(.018)$ \\
\hline \multirow[t]{2}{*}{ More than 20 Years } & -.090 & -.120 & .123 & .160 & .236 & .271 \\
\hline & $(.049)$ & $(.053)$ & $(.046)$ & $(.051)$ & $(.020)$ & $(.022)$ \\
\hline \multicolumn{7}{|l|}{ Immigrant Arrival Cohort: } \\
\hline \multirow[t]{2}{*}{ Pre-1961 } & & & -.083 & -.019 & -.102 & -.056 \\
\hline & & & $(.052)$ & $(.064)$ & $(.023)$ & $(.028)$ \\
\hline \multirow[t]{2}{*}{$1961-65$} & & & -.109 & -.042 & -.135 & -.082 \\
\hline & & & $(.047)$ & $(.057)$ & $(.020)$ & $(.024)$ \\
\hline \multirow[t]{2}{*}{$1966-70$} & & & -.102 & -.087 & -.224 & -.146 \\
\hline & & & $(.038)$ & $(.049)$ & $(.017)$ & $(.022)$ \\
\hline \multirow[t]{2}{*}{ Pre-1971 } & -.009 & .065 & & & & \\
\hline & $(.046)$ & $(.060)$ & & & & \\
\hline \multirow[t]{2}{*}{$1971-75$} & -.058 & .004 & -.174 & -.139 & -.253 & -.142 \\
\hline & $(.048)$ & $(.057)$ & $(.045)$ & $(.049)$ & $(.018)$ & $(.020)$ \\
\hline \multirow[t]{2}{*}{$1976-80$} & -.040 & -.009 & -.222 & -.196 & -.300 & -.206 \\
\hline & $(.025)$ & $(.038)$ & $(.021)$ & $(.029)$ & $(.009)$ & $(.013)$ \\
\hline \multirow[t]{2}{*}{$1981-85$} & -.137 & -.100 & -.239 & -.206 & -.338 & -.230 \\
\hline & $(.053)$ & $(.053)$ & $(.048)$ & $(.048)$ & $(.018)$ & $(.017)$ \\
\hline \multirow[t]{2}{*}{$1986-91$} & -.077 & -.098 & -.393 & -.354 & -.373 & -.271 \\
\hline & $(.023)$ & $(.024)$ & $(.021)$ & $(.021)$ & $(.008)$ & $(.009)$ \\
\hline \multirow[t]{2}{*}{ 1990/91 Census Dummy } & .705 & .560 & .510 & .337 & .435 & .354 \\
\hline & $(.016)$ & $(.031)$ & $(.009)$ & $(.018)$ & $(.013)$ & $(.016)$ \\
\hline $\mathrm{R}^{2}$ & .334 & .369 & .148 & .189 & .184 & .288 \\
\hline Controls for Education & No & Yes & No & Yes & No & Yes \\
\hline
\end{tabular}

Note: The dependent variable is the natural logarithm of weekly personal income (for Australia) or weekly earnings (for Canada and the United States). The coefficients were estimated by least squares, and robust standard errors are shown in parentheses. Data are from the 1981 and 1991 Australian and Canadian censuses and the 1980 and 1990 U.S. censuses. The samples include employed men ages 25-59, with non-whites excluded from the native but not the foreign-born samples. The sample sizes for these regressions are 43,590 for Australia, 217,773 for Canada, and 359,999 for the United States. In addition to the variables listed above, all regressions include indicators for age, geographic location, and hours worked during the census survey week. The coefficients of the controls for geographic location and weekly hours of work are restricted to be the same for immigrants and natives, but these coefficients can differ across census years. The coefficients of the age and education variables are allowed to vary both by nativity and census year. The reference group for the "time in destination country" dummies is $0-5$ years. The intervals listed above for the immigrant arrival cohorts are those defined in the Australian and Canadian data; the slightly different immigrant cohorts defined in the U.S. data are as follows: pre-1960, 1960-64, 1965-69, 1970-74, 1975-79, 1980-84, and 1985-90. The immigrant cohort coefficients reported in this table have been normalized to represent immigrant-native wage differentials for men who are aged 25-29 (in both specifications) and who have 12 years of education in 1990/91 (in specification (2)). 
Table 6

Components of Immigrant Earnings Growth from Assimilation

\section{A. Without Education Controls}

\begin{tabular}{|c|c|c|c|}
\hline \multicolumn{4}{|c|}{ Australia } \\
\hline \multicolumn{3}{|c|}{$\begin{array}{l}\text { Percentage Earnings Growth } \\
\text { from Assimilation in: }\end{array}$} & $\begin{array}{l}\text { Percent } \\
\text { of Total } \\
\text { Due to }\end{array}$ \\
\hline Emp & Wage & Total & Emp \\
\hline
\end{tabular}

\begin{tabular}{|c|c|c|c|}
\hline \multicolumn{4}{|c|}{ Canada } \\
\hline $\begin{array}{r}\text { Percen } \\
\text { fro }\end{array}$ & $\begin{array}{l}\text { Earnir } \\
\text { Assimila }\end{array}$ & $\begin{array}{l}\text { Growth } \\
\text { in: }\end{array}$ & $\begin{array}{l}\text { Percent } \\
\text { of Total } \\
\text { Due to }\end{array}$ \\
\hline Emp & Wage & Total & Emp \\
\hline
\end{tabular}

\begin{tabular}{|c|c|c|c|}
\hline \multicolumn{4}{|c|}{ United States } \\
\hline $\begin{array}{r}\text { Percer } \\
\text { fro }\end{array}$ & $\begin{array}{l}\text { e Earnin } \\
\text { Assimila }\end{array}$ & $\begin{array}{l}\text { Growth } \\
\text { in: }\end{array}$ & $\begin{array}{l}\text { Percent } \\
\text { of Total } \\
\text { Due to }\end{array}$ \\
\hline Emp & Wage & Total & Emp \\
\hline
\end{tabular}

Time in Destination Country:

\begin{tabular}{|c|c|c|c|c|c|c|c|c|c|c|c|c|}
\hline 6-10 Years & $\begin{array}{l}13.5 \\
(3.9)\end{array}$ & $\begin{array}{c}3.2 \\
(4.7)\end{array}$ & $\begin{array}{l}16.7 \\
(6.1)\end{array}$ & 80.9 & $\begin{array}{c}5.3 \\
(2.2)\end{array}$ & $\begin{array}{c}4.6 \\
(4.3)\end{array}$ & $\begin{array}{c}9.9 \\
(4.8)\end{array}$ & 53.7 & $\begin{array}{c}12.5 \\
(0.8)\end{array}$ & $\begin{array}{c}5.2 \\
(1.7)\end{array}$ & $\begin{array}{l}17.7 \\
(1.9)\end{array}$ & 70.7 \\
\hline 11-15 Years & $\begin{array}{l}15.0 \\
(3.1)\end{array}$ & $\begin{array}{l}-6.3 \\
(3.7)\end{array}$ & $\begin{array}{c}8.7 \\
(4.8)\end{array}$ & $>100$ & $\begin{array}{c}8.2 \\
(1.6)\end{array}$ & $\begin{array}{l}11.1 \\
(2.8)\end{array}$ & $\begin{array}{c}19.3 \\
(3.2)\end{array}$ & 42.5 & $\begin{array}{l}14.3 \\
(0.6)\end{array}$ & $\begin{array}{c}14.4 \\
(1.1)\end{array}$ & $\begin{array}{c}28.7 \\
(1.3)\end{array}$ & 49.9 \\
\hline $16-20$ Years & $\begin{array}{c}16.2 \\
(3.6)\end{array}$ & $\begin{array}{l}-6.1 \\
(4.4)\end{array}$ & $\begin{array}{l}10.1 \\
(5.7)\end{array}$ & $>100$ & $\begin{array}{l}11.3 \\
(2.3)\end{array}$ & $\begin{array}{c}9.4 \\
(4.5)\end{array}$ & $\begin{array}{c}20.7 \\
(5.1)\end{array}$ & 54.7 & $\begin{array}{l}14.6 \\
(0.9)\end{array}$ & $\begin{array}{l}15.8 \\
(1.8)\end{array}$ & $\begin{array}{c}30.4 \\
(2.0)\end{array}$ & 48.0 \\
\hline
\end{tabular}

\section{B. With Education Controls}

Time in Destination Country:

\begin{tabular}{|c|c|c|c|c|c|c|c|c|c|c|}
\hline 6-10 Years & $\begin{array}{l}13.3 \\
(3.9)\end{array}$ & $\begin{array}{c}0.9 \\
(4.6)\end{array}$ & $\begin{array}{l}14.2 \\
(6.0)\end{array}$ & 93.6 & $\begin{array}{c}4.2 \\
(2.2)\end{array}$ & $\begin{array}{c}5.2 \\
(4.2)\end{array}$ & $\begin{array}{c}9.4 \\
(4.7)\end{array}$ & 44.9 & $\begin{array}{c}12.7 \\
(0.8)\end{array}$ & $\begin{array}{c}7.0 \\
(1.5)\end{array}$ \\
\hline 11-15 Years & $\begin{array}{l}16.1 \\
(3.3)\end{array}$ & $\begin{array}{l}-8.6 \\
(3.9)\end{array}$ & $\begin{array}{c}7.5 \\
(5.1)\end{array}$ & $>100$ & $\begin{array}{c}7.5 \\
(1.8)\end{array}$ & $\begin{array}{l}13.9 \\
(3.1)\end{array}$ & $\begin{array}{l}21.4 \\
(3.6)\end{array}$ & 35.1 & $\begin{array}{c}13.9 \\
(0.6)\end{array}$ & $\begin{array}{l}18.3 \\
(1.2)\end{array}$ \\
\hline 16-20 Years & $\begin{array}{c}17.4 \\
(3.9)\end{array}$ & $\begin{array}{l}-8.7 \\
(4.6)\end{array}$ & $\begin{array}{c}8.7 \\
(6.0)\end{array}$ & $>100$ & $\begin{array}{c}9.6 \\
(2.6)\end{array}$ & $\begin{array}{l}11.5 \\
(4.7)\end{array}$ & $\begin{array}{l}21.1 \\
(5.4)\end{array}$ & 45.4 & $\begin{array}{l}14.3 \\
(1.0)\end{array}$ & $\begin{array}{c}20.3 \\
(1.8)\end{array}$ \\
\hline More than 20 Years & $\begin{array}{c}18.7 \\
(4.4)\end{array}$ & $\begin{array}{r}-12.0 \\
(5.3)\end{array}$ & $\begin{array}{c}6.7 \\
(6.9)\end{array}$ & $>100$ & $\begin{array}{l}11.7 \\
(2.9)\end{array}$ & $\begin{array}{l}16.0 \\
(5.1)\end{array}$ & $\begin{array}{l}27.7 \\
(5.9)\end{array}$ & 42.3 & $\begin{array}{c}15.5 \\
(1.3)\end{array}$ & $\begin{array}{c}27.1 \\
(2.2)\end{array}$ \\
\hline
\end{tabular}

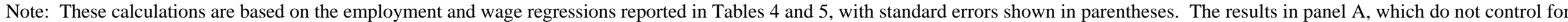

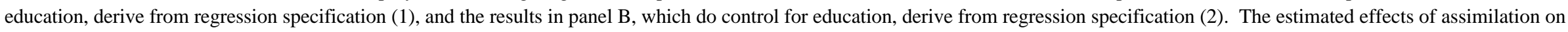

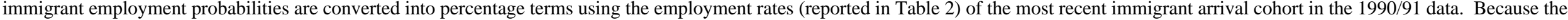

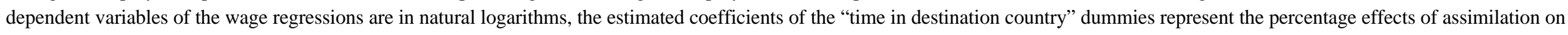

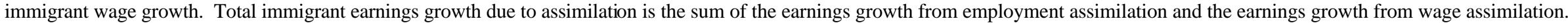


Table 7

\section{Employment Regressions, by Region of Origin} Assimilation, Cohort and Period Effects

European Immigrants to:

$\underline{\text { Regressor }}$

Time in Destination Country:
6-10 Years

11-15 Years

16-20 Years

More than 20 Years

Immigrant Arrival Cohort:

Pre-1961

1961-65

1966-70

Pre-1971

1971-75

1976-80

1981-85

1986-91

1990/91 Census Dummy

$\mathrm{R}^{2}$

\begin{tabular}{|c|c|c|}
\hline Australia & Canada & United State \\
\hline $\begin{array}{c}.105 \\
(.037) \\
.101 \\
(.031) \\
.109 \\
(.036) \\
.110 \\
(.039)\end{array}$ & $\begin{array}{c}.058 \\
(.021) \\
.060 \\
(.016) \\
.089 \\
(.023) \\
.095 \\
(.025)\end{array}$ & $\begin{array}{c}.060 \\
(.013) \\
.070 \\
(.009) \\
.073 \\
(.013) \\
.084 \\
(.014)\end{array}$ \\
\hline & $\begin{array}{l}-.065 \\
(.028) \\
-.061 \\
(.025) \\
-.042 \\
(.022)\end{array}$ & $\begin{array}{l}-.087 \\
(.017) \\
-.075 \\
(.015) \\
-.084 \\
(.013)\end{array}$ \\
\hline
\end{tabular}

$-.147$

(.038)

$-.145$

(.040)

$-.057$

$(.023)$

$-.002$

(.013)

(.026)

$-.020$

$(.025)$

$(.045)$

$-.072$

(.015)

(.027)

$\begin{array}{ll}-.077 \quad-.055 \\ (.011) & (.004)\end{array}$

(.011)

(.004)

.029

.030

-.088
$(.014)$
-.072
$(.008)$
-.063
$(.014)$
-.116
$(.008)$

-.014
$(.008)$

.021

Asian Immigrants to:

\begin{tabular}{|c|c|c|}
\hline Australia & Canada & United States \\
\hline .210 & .048 & .124 \\
\hline$(.074)$ & $(.046)$ & $(.012)$ \\
\hline .161 & .090 & .168 \\
\hline$(.054)$ & $(.021)$ & $(.008)$ \\
\hline .221 & .120 & .155 \\
\hline (.069) & $(.047)$ & $(.013)$ \\
\hline .173 & .146 & .189 \\
\hline$(.083)$ & $(.040)$ & $(.016)$ \\
\hline
\end{tabular}

$\begin{array}{ll}-.094 & -.221 \\ (.050) & (.019)\end{array}$

(.050) (.019)

$\begin{array}{ll}-.059 & -.192\end{array}$

(.049) (.015)

$\begin{array}{ll}-.059 & -.208\end{array}$

(.032) (.013)

$-.196$

(.078)

$\begin{array}{lll}-.259 & -.063 & -.180\end{array}$

$\begin{array}{lll}(.074) & (.047) \quad(.012)\end{array}$

$\begin{array}{lll}-.231 & -.093 & -.219\end{array}$

$\begin{array}{lll}(.042) & (.016) & (.006)\end{array}$

$\begin{array}{lll}-.340 & -.083 & -.217\end{array}$

$\begin{array}{lll}(.081) & (.048) & (.013)\end{array}$

$\begin{array}{lll}-.193 & -.141 & -.199\end{array}$

$\begin{array}{lll}(.029) & (.013) \quad(.006)\end{array}$

$\begin{array}{lll}-.076 & -.056 & -.019\end{array}$

$\begin{array}{lll}.010) & (.004) \quad(.008)\end{array}$

$\begin{array}{lll}.035 & .033 & .052\end{array}$

Note: The dependent variable is a dummy identifying whether the individual was employed during the census survey week. The coefficients were estimated by least squares, and robust standard errors are shown in parentheses. Data are from the 1981 and 1991 Australian and Canadian censuses and the 1980 and 1990 U.S. censuses. The samples include men ages 25-59, with non-whites excluded from the native but not the foreign-born samples. In these particular regressions, the only immigrants included are those born in Europe (left three columns) or those born in Asia (right three columns). Sample sizes for the regressions with European immigrants are 48,018 in Australia, 238,166 in Canada, and 154,572 in the United States. Sample sizes for the regressions with Asian immigrants are 41,870 in Australia, 224,704 in Canada, and 175,346 in the United States. In addition to the variables listed above, all regressions include indicators for age and geographic location. The coefficients of the geographic controls are restricted to be the same for immigrants and natives, but these coefficients can differ across census years. The coefficients of the age variables are allowed to vary both by nativity and census year. The reference group for the "time in destination country" dummies is 0-5 years. The intervals listed above for the immigrant arrival cohorts are those defined in the Australian and Canadian data; the slightly different immigrant cohorts defined in the U.S. data are as follows: pre-1960, 1960-64, 1965-69, 1970-74, 1975-79, 1980-84, and 1985-90. The immigrant cohort coefficients reported in this table have been normalized to represent immigrant-native employment differentials for men who are aged 25-29. 
Table 8

\section{Wage Regressions, by Region of Origin}

Assimilation, Cohort and Period Effects

\begin{tabular}{|c|c|c|c|c|c|c|}
\hline \multirow[b]{2}{*}{ Regressor } & \multicolumn{3}{|c|}{ European Immigrants to: } & \multicolumn{3}{|c|}{ Asian Immigrants to: } \\
\hline & Australia & Canada & United States & Australia & Canada & United States \\
\hline \multicolumn{7}{|c|}{ Time in Destination Country: } \\
\hline \multirow{2}{*}{ 6-10 Years } & .085 & .075 & .041 & .049 & .118 & .030 \\
\hline & $(.063)$ & $(.059)$ & $(.033)$ & $(.111)$ & $(.125)$ & $(.035)$ \\
\hline \multirow[t]{2}{*}{ 11-15 Years } & -.032 & .146 & .135 & .017 & .144 & .290 \\
\hline & $(.051)$ & $(.044)$ & $(.021)$ & $(.082)$ & $(.049)$ & $(.018)$ \\
\hline \multirow[t]{2}{*}{ 16-20 Years } & -.026 & .154 & .173 & .110 & .217 & .302 \\
\hline & $(.059)$ & $(.061)$ & $(.033)$ & $(.101)$ & $(.127)$ & $(.037)$ \\
\hline \multirow[t]{2}{*}{ More than 20 Years } & -.066 & .200 & .226 & .124 & .135 & .513 \\
\hline & $(.064)$ & $(.065)$ & $(.034)$ & $(.128)$ & $(.096)$ & $(.038)$ \\
\hline \multicolumn{7}{|l|}{ Immigrant Arrival Cohort: } \\
\hline \multirow[t]{2}{*}{ Pre-1961 } & & -.124 & -.053 & & -.162 & -.192 \\
\hline & & $(.071)$ & $(.039)$ & & $(.114)$ & $(.044)$ \\
\hline \multirow[t]{2}{*}{$1961-65$} & & -.172 & -.092 & & -.009 & -.085 \\
\hline & & $(.065)$ & $(.036)$ & & $(.122)$ & $(.038)$ \\
\hline \multirow[t]{2}{*}{$1966-70$} & & -.128 & -.135 & & -.022 & -.172 \\
\hline & & $(.056)$ & $(.030)$ & & $(.077)$ & $(.030)$ \\
\hline \multirow[t]{2}{*}{ Pre-1971 } & -.039 & & & -.208 & & \\
\hline & $(.060)$ & & & $(.123)$ & & \\
\hline \multirow[t]{2}{*}{$1971-75$} & -.099 & -.090 & -.148 & -.218 & -.292 & -.048 \\
\hline & $(.063)$ & $(.061)$ & $(.034)$ & $(.114)$ & $(.125)$ & $(.036)$ \\
\hline \multirow[t]{2}{*}{$1976-80$} & -.027 & -.041 & -.070 & -.237 & -.355 & -.260 \\
\hline & $(.033)$ & $(.034)$ & $(.017)$ & $(.065)$ & $(.036)$ & $(.013)$ \\
\hline \multirow[t]{2}{*}{$1981-85$} & -.135 & -.025 & .020 & -.346 & -.413 & -.197 \\
\hline & $(.071)$ & $(.067)$ & $(.036)$ & $(.120)$ & $(.129)$ & $(.037)$ \\
\hline \multirow[t]{2}{*}{$1986-91$} & .043 & -.165 & -.009 & -.270 & -.485 & -.255 \\
\hline & $(.037)$ & $(.035)$ & $(.016)$ & $(.040)$ & $(.032)$ & $(.012)$ \\
\hline \multirow[t]{2}{*}{ 1990/91 Census Dummy } & .729 & .506 & .436 & .733 & .510 & .507 \\
\hline & $(.017)$ & $(.010)$ & $(.018)$ & $(.017)$ & $(.010)$ & $(.017)$ \\
\hline $\mathrm{R}^{2}$ & .337 & .149 & .190 & .330 & .150 & .216 \\
\hline
\end{tabular}

Note: The dependent variable is the natural logarithm of weekly personal income (for Australia) or weekly earnings (for Canada and the United States). The coefficients were estimated by least squares, and robust standard errors are shown in parentheses. Data are from the 1981 and 1991 Australian and Canadian censuses and the 1980 and 1990 U.S. censuses. The samples include employed men ages 25-59, with non-whites excluded from the native but not the foreign-born samples. In these particular regressions, the only immigrants included are those born in Europe (left three columns) or those born in Asia (right three columns). Sample sizes for the regressions with European immigrants are 40,119 in Australia, 200,869 in Canada, and 134,284 in the United States. Sample sizes for the regressions with Asian immigrants are 34,951 in Australia, 188,399 in Canada, and 148,132 in the United States. In addition to the variables listed above, all regressions include indicators for age, geographic location, and hours worked during the census survey week. The coefficients of the controls for geographic location and weekly hours of work are restricted to be the same for immigrants and natives, but these coefficients can differ across census years. The coefficients of the age variables are allowed to vary both by nativity and census year. The reference group for the "time in destination country" dummies is $0-5$ years. The intervals listed above for the immigrant arrival cohorts are those defined in the Australian and Canadian data; the slightly different immigrant cohorts defined in the U.S. data are as follows: pre1960, 1960-64, 1965-69, 1970-74, 1975-79, 1980-84, and 1985-90. The immigrant cohort coefficients reported in this table have been normalized to represent immigrant-native wage differentials for men who are aged 25-29. 
Table 9

Components of Immigrant Earnings Growth from Assimilation, by Region of Origin

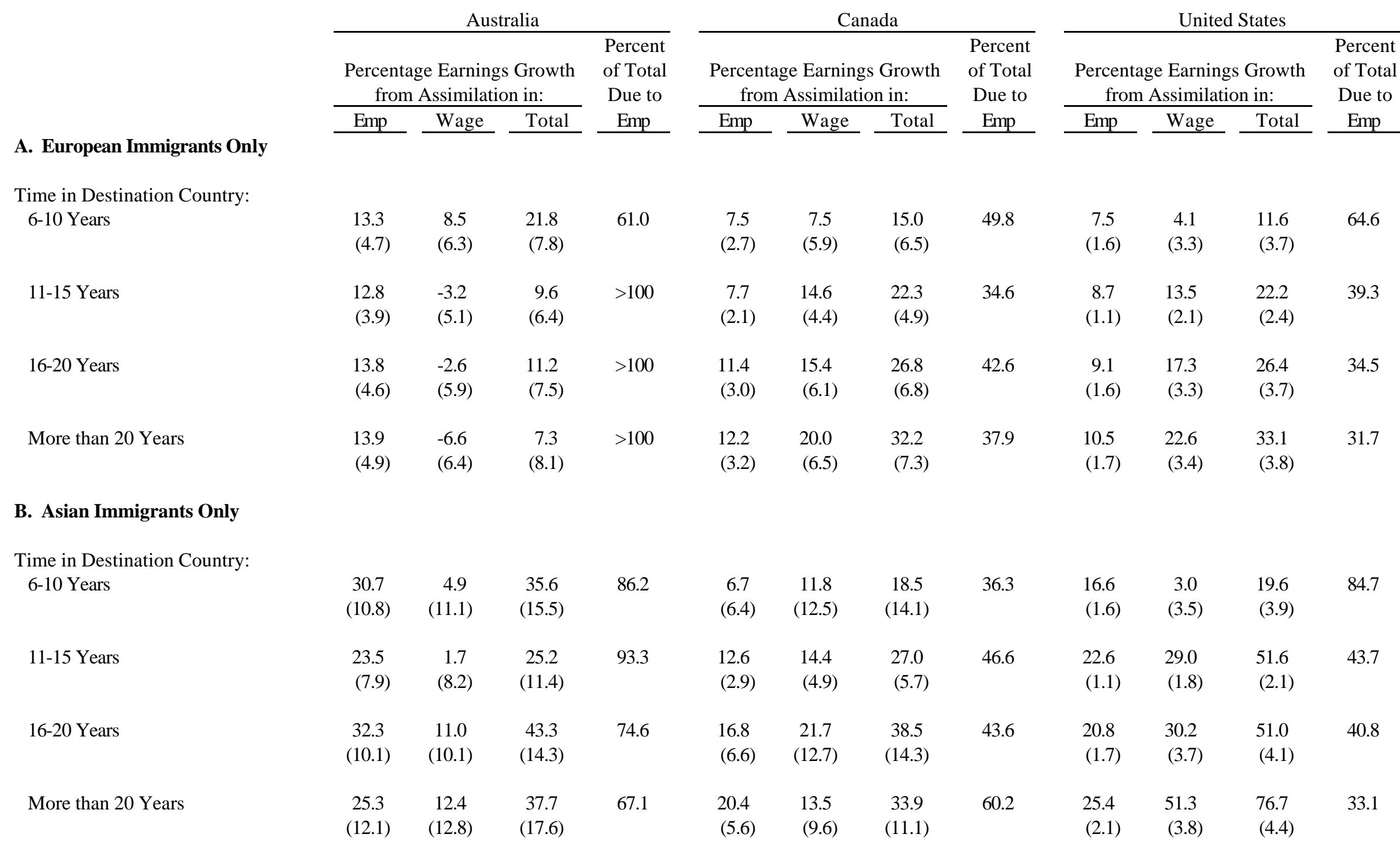

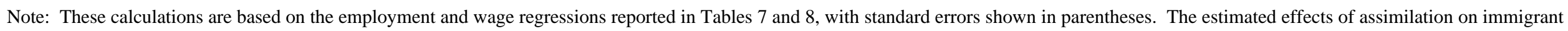

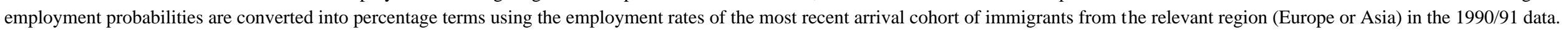

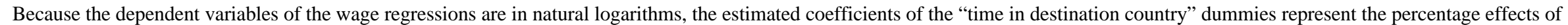

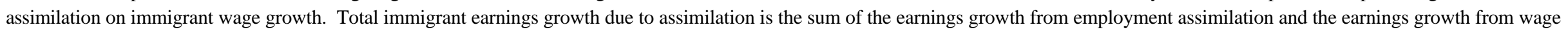
assimilation. 


\section{IZA Discussion Papers}

No.

Author(s)

J. A. Cabral Vieira

A. R. Cardoso

M. Portela

790

A. Cigno

A. Luporini

A. Pettini

791

792

793

794

795

796

797

798

799

800

801

802
T. Beissinger

C. Knoppik

M. Güell

L. Borghans

B. ter Weel

T. Palokangas

P. Frijters

M. A. Shields

S. Wheatley Price

B. T. Hirsch

P. Apps

E. Bratberg

Ø. A. Nilsen

K. Vaage

J. J. Heckman

J. A. Smith

R. A. Hart

A. Launov

H. Antecol

P. Kuhn

S. J. Trejo
Title

Area

Date

Recruitment and Pay at the Establishment

5

06/03

Level: Gender Segregation and the Wage Gap

in Portugal

Hidden Information Problems in the Design of

3

06/03

Family Allowances

Fixed-Term Contracts and the Duration

Distribution of Unemployment

What Happens When Agent T Gets a

Computer? The Labor Market Impact of Cost

Efficient Computer Adoption

Foreign Direct Investment, Labour Market

3

Regulation and Self-Interested Governments

Investigating the Quitting Decision of Nurses:

Panel Data Evidence from the British National

Health Service

Reconsidering Union Wage Effects: Surveying 3 New Evidence on an Old Topic

Gender, Time Use and Models of the Household

5

06/03

Assessing Changes in Intergenerational

Earnings Mobility

2

06/03

The Determinants of Participation in a Social

6

06/03

Program: Evidence from a Prototypical Job

Training Program

General Human Capital and Employment

2

06/03

Adjustment in the Great Depression:

Apprentices and Journeymen in UK Engineering

Sind Nominallöhne starr? Neuere Evidenz und $\quad 7$

wirtschaftspolitische Implikationen

06/03

A Study of the Austrian Labor Market Dynamics 2 Using a Model of Search Equilibrium

06/03

Assimilation via Prices or Quantities? Labor

Market Institutions and Immigrant Earnings

Growth in Australia, Canada, and the United

States

An updated list of IZA Discussion Papers is available on the center's homepage www.iza.org. 